\title{
Molecular composition of particulate matter emissions from dung and brushwood burning household cookstoves in Haryana, India
}

\author{
Lauren T. Fleming ${ }^{1}$, Peng Lin ${ }^{2}$, Alexander Laskin ${ }^{2}$, Julia Laskin $^{2}$, Robert Weltman $^{3}$, Rufus D. Edwards ${ }^{3}$, \\ Narendra K. Arora ${ }^{4}$, Ankit Yadav ${ }^{4}$, Simone Meinardi ${ }^{1}$, Donald R. Blake ${ }^{1}$, Ajay Pillarisetti ${ }^{5}$, Kirk R. Smith ${ }^{5}$, and \\ Sergey A. Nizkorodov ${ }^{1}$ \\ ${ }^{1}$ Department of Chemistry, University of California, Irvine, CA 92617, USA \\ ${ }^{2}$ Department of Chemistry, Purdue University, West Lafayette, IN 47907, USA \\ ${ }^{3}$ Department of Epidemiology, University of California, Irvine, CA, 92617, USA \\ ${ }^{4}$ The Inclen Trust, Okhla Industrial Area, Phase-I, New Delhi-110020, India \\ ${ }^{5}$ School of Public Health, University of California, Berkeley, CA 94720, USA
}

Correspondence: Rufus D. Edwards (edwardsr@uci.edu) and Sergey A. Nizkorodov (nizkorod@uci.edu)

Received: 23 August 2017 - Discussion started: 1 September 2017

Revised: 27 December 2017 - Accepted: 10 January 2018 - Published: 19 February 2018

\begin{abstract}
Emissions of airborne particles from biomass burning are a significant source of black carbon (BC) and brown carbon $(\mathrm{BrC})$ in rural areas of developing countries where biomass is the predominant energy source for cooking and heating. This study explores the molecular composition of organic aerosols from household cooking emissions with a focus on identifying fuel-specific compounds and $\mathrm{BrC}$ chromophores. Traditional meals were prepared by a local cook with dung and brushwood-fueled cookstoves in a village in Palwal district, Haryana, India. Cooking was done in a village kitchen while controlling for variables including stove type, fuel moisture, and meal. Fine particulate matter $\left(\mathrm{PM}_{2.5}\right)$ emissions were collected on filters, and then analyzed via nanospray desorption electrospray ionization-highresolution mass spectrometry (nano-DESI-HRMS) and highperformance liquid chromatography-photodiode array-highresolution mass spectrometry (HPLC-PDA-HRMS) techniques. The nano-DESI-HRMS analysis provided an inventory of numerous compounds present in the particle phase. Although several compounds observed in this study have been previously characterized using gas chromatography methods a majority of the species in the nano-DESI spectra were newly observed biomass burning compounds. Both the stove (chulha or angithi) and the fuel (brushwood or dung) affected the composition of organic aerosols. The geometric mean of the $\mathrm{PM}_{2.5}$ emission factor and the observed molecular complexity increased in the following or-
\end{abstract}

der: brushwood-chulha $\left(7.3 \pm 1.8 \mathrm{~g} \mathrm{~kg}^{-1}\right.$ dry fuel, $93 \mathrm{com}$ pounds), dung-chulha $\left(21.1 \pm 4.2 \mathrm{~g} \mathrm{~kg}^{-1}\right.$ dry fuel, $212 \mathrm{com}$ pounds), and dung-angithi (29.8 $\pm 11.5 \mathrm{~g} \mathrm{~kg}^{-1}$ dry fuel, 262 compounds). The mass-normalized absorption coefficient $\left(\mathrm{MAC}_{\text {bulk }}\right)$ for the organic-solvent extractable material for brushwood $\mathrm{PM}_{2.5}$ was $3.7 \pm 1.5$ and $1.9 \pm 0.8 \mathrm{~m}^{2} \mathrm{~g}^{-1}$ at 360 and $405 \mathrm{~nm}$, respectively, which was approximately a factor of two higher than that for dung $\mathrm{PM}_{2.5}$. The HPLCPDA-HRMS analysis showed that, regardless of fuel type, the main chromophores were $\mathrm{C}_{x} \mathrm{H}_{y} \mathrm{O}_{z}$ lignin fragments. The main chromophores accounting for the higher $\mathrm{MAC}_{\text {bulk }}$ values of brushwood $\mathrm{PM}_{2.5}$ were $\mathrm{C}_{8} \mathrm{H}_{10} \mathrm{O}_{3}$ (tentatively assigned to syringol), nitrophenols $\mathrm{C}_{8} \mathrm{H}_{9} \mathrm{NO}_{4}$, and $\mathrm{C}_{10} \mathrm{H}_{10} \mathrm{O}_{3}$ (tentatively assigned to methoxycinnamic acid).

\section{Introduction}

Approximately 3 billion people live in residences where solid fuels (coal, wood, charcoal, dung, and crop residues) are combusted for cooking (Smith et al., 2014). Approximately $57 \%$ of Indian households report use of wood (49\%) or crop residues $(9 \%)$ as their primary cook fuels, while $8 \%$ report dung as a primary cook fuel (Census of India, 2011). However, many households will routinely use two or more of these fuels in combination for their cooking needs in simple, home-made traditional stoves, or chulhas. These biomass 
burning cookstoves have low combustion efficiencies and produce significant emissions of pollutants, including fine particulate matter $\left(\mathrm{PM}_{2.5}\right)$.

Epidemiological literature statistically links household air pollution from solid biomass combustion to acute lower respiratory infections in children; heart disease, stroke, cataracts, cancers in adults; and low birth weight for infants of women exposed during pregnancy (Smith et al., 2014). $\mathrm{PM}_{2.5}$ are small enough to infiltrate deep into the lungs and penetrate the body's defenses, and therefore $\mathrm{PM}_{2.5}$ exposure has been commonly used for estimating risks from both ambient air pollution and cigarette smoke (Finlayson-Pitts and Pitts, 2000). The degree of adverse health effects of cookstove smoke likely depends on the chemical composition of the $\mathrm{PM}_{2.5}$. However, the exact relationship between the chemical composition and its health effects is largely unknown (Araujo et al., 2008).

Household cooking is estimated to be responsible for 26$50 \%$ of ambient $\mathrm{PM}_{2.5}$ in India (Chafe et al., 2014; Guttikunda et al., 2016; Lelieveld et al., 2015). In this emissions mixture, carbonaceous particles affect the climate directly by scattering and absorbing incoming solar radiation and indirectly by acting as cloud condensation nuclei (Crutzen and Andreae, 1990). In addition to black carbon (BC), which absorbs solar radiation across the entire visible spectrum, some molecules in biomass burning organic aerosols (BBOA) efficiently absorb blue and near-UV solar radiation resulting in classification of BBOA as brown carbon $(\mathrm{BrC})$ (Laskin et al., 2015). Modeling studies have shown that in certain geographic areas climate warming by $\mathrm{BrC}$ has the potential to outweigh cooling by scattering organic aerosols (Feng et al., 2013). South Asia has been identified as one of these unique regions where emissions from cookstoves are a significant source of regional $\mathrm{BrC}$ (Feng et al., 2013).

Cookstove emissions have been studied in both laboratory and field settings. Field studies typically involve observations and measurements during daily cooking activities in rural village homes. For example, Xiao et al. (2015) measured $\mathrm{BC}$ and $\mathrm{PM}_{2.5}$ throughout the day for six different houses to monitor indoor concentrations in the household. In the laboratory, water boiling test (WBT) protocols are utilized to evaluate stove performance (Global Alliance for Clean Cookstoves, 2014). The WBT standard protocols are made up of three phases to represent the stove's combustion efficiency while cooking: (1) high power, cold start; (2) high power, hot start; and (3) low power, simmer (Global Alliance for Clean Cookstoves, 2014). While the WBTs can be carried out under more controlled conditions, recent studies have found that the WBTs fail to capture periods of low combustion efficiency in cooking events (Chen et al., 2012; Johnson et al., 2008, 2009). This is due to daily cooking activities involving more than just boiling water (Johnson et al., 2009). Some cooking techniques require a smoldering fire, for example the cooking of chapatti, a traditional Indian flat bread (Johnson et al., 2009). Alternately, these low combus- tion efficiency periods may be a consequence of multitasking around the home (Johnson et al., 2009). The literature estimates that emissions of $\mathrm{PM}_{2.5}$ (Roden et al., 2009) and $\mathrm{CO} / \mathrm{CO}_{2}$ ratios (Johnson et al., 2008; Kituyi et al., 2001; Ludwig et al., 2003) are underrepresented by the WBTs relative to field measurements by a factor of 3 . There are also concerns that WBTs cannot be scaled to real cooking events and that climate models may underrepresent global emissions from biomass burning cookstoves (Chen et al., 2012; Johnson et al., 2008, 2009).

A number of studies have characterized the optical properties of cookstove BBOA. Depending on the measurement approach, different metrics of aerosol absorption have been reported. In general, methods that take direct measurements of aerosol particles without extraction report mass-normalized absorption cross sections of aerosols $\left(\mathrm{MAC}_{\text {aerosol }}\right)$. Absorption measurements with the extracted material report mass-normalized absorption cross sections of bulk material $\left(\mathrm{MAC}_{\text {bulk }}\right)$. In this paper, we use a subscript "bulk" to help minimize confusion between $\mathrm{MAC}_{\text {bulk }}$ and $\mathrm{MAC}_{\text {aerosol }}$. The two can be related if the particle size distribution is known (Laskin et al., 2015). An advantage of $\mathrm{MAC}_{\text {bulk }}$ is that it can be used to calculate the imaginary refractive index of the organic material (Laskin et al., 2015). For particles that are made of material with a real refractive index of 1.5 and that are small in diameter relative to the wavelength, $\mathrm{MAC}_{\text {aerosol }} \sim 0.7 \times \mathrm{MAC}_{\text {bulk }}$ (Laskin et al., 2015).

Stockwell et al. (2016) utilized photoacoustic extinctiometers (PAX) to conduct in situ absorption measurements at 405 and $870 \mathrm{~nm}$, resulting in particle absorption coefficients from cook fire emissions in Nepal. With a literature-recommended mass absorption coefficient for light-absorbing organic compounds (Lack and Langridge, 2013) and the measured aerosol absorption by PAX, Stockwell et al., (2016) approximated particle absorption emission factors (EFs) due to the light-absorbing organic compounds in particles. Organic carbon (OC) absorption EFs were 1.5 times higher for the hardwood smoke $\left(\mathrm{EF}=8.40 \mathrm{~g} \mathrm{~kg}^{-1}\right.$ fuel $)$ compared to the dung smoke $\left(E F=5.43 \mathrm{~g} \mathrm{~kg}^{-1}\right.$ fuel). Pandey et al. (2016) collected $\mathrm{PM}_{2.5}$ on filters from cook fires in India, that were fueled by wood, agricultural residues, dung, and a mixture thereof and reported $\mathrm{MAC}_{\mathrm{aerosol}}$ values. They found that the $\mathrm{MAC}_{\text {aerosol }}$ at $550 \mathrm{~nm}$ was a factor of 2.6 higher for wood fuel $\left(1.3 \mathrm{~m}^{2} \mathrm{~g}^{-1}\right)$ compared to dung fuel $\left(0.5 \mathrm{~m}^{2} \mathrm{~g}^{-1}\right)$ (Pandey et al., 2016). This is consistent with Saleh et al. (2014), who found that the effective absorptivity of OA in BBOA increases with BC-OA ratio. In Pandey et al. (2016), they measured EC / OC at 0.0649 for dung, and 0.0826 for wood fuel.

Many organic components of BBOA have been successfully characterized in previous studies by electrospray ionization high-resolution mass spectrometry (ESI-HRMS) (Budisulistiorini et al., 2017; Laskin et al., 2009; Lin et al., 2012, 2016, 2017; Smith et al., 2009; Wang et al., 2017; Willoughby et al., 2016). For example, ESI-HRMS was used to analyze the particle-phase organic constituents of smoke 
samples collected during the Fire Lab at Missoula Experiment (FLAME) campaign (Laskin et al., 2009; Smith et al., 2009). Fuels utilized in the FLAME studies were selected to represent North American wildfires and the publications focused on nonwoody biomass fuels such as detritus and litter as well as ceanothus from the US Pacific Northwest. Smith et al. (2009) reported an inventory of species in particlephase BBOA, with $70 \%$ of the compounds being reported for the first time. Laskin et al. (2009) examined the nitrogencontaining species and observed that a large fraction of the detected species were $\mathrm{N}$-heterocyclic compounds. Lin et al. (2016) identifies fuel-specific BrC chromophores in particles collected from FLAME-4 via high-performance liquid chromatography combined with photodiode array and highresolution mass spectrometry (HPLC-PDA-HRMS). Two of the four fuels were woody biomass specific to North America. They found that nitroaromatics, polycyclic aromatic hydrocarbons (PAHs), and polyphenols were responsible for the light absorption by BBOA (Lin et al., 2016). Recent papers investigated the chromophores in BBOA from Lag Ba'Omer, a nationwide bonfire festival in Israel (Bluvshtein et al., 2017; Lin et al., 2017). They found nitroaromatics to be the most prominent chromophores in these samples. Budisulistiorini et al. (2017) similarly identified 41 chromophores from Indonesian peat, charcoal, and fern or leaf burning with a method relying on chromatographic separation and simultaneous detection by spectrophotometry and ESI-MS. They identified three types of chromophores: oxygenated, nitroaromatics, and sulfur-containing (Budisulistiorini et al., 2017).

The goal of the current study is to understand the composition of cookstove BBOA in additional detail than afforded by previous measurements. We do this by (1) generating and collecting BBOA from prescribed cooking events carried out by a local cook and (2) using high-resolution mass spectrometry techniques to characterize their particle-phase composition. This is part of a larger study attempting to document the contribution of household solid fuel combustion to air pollution in India.

In this paper we provide an inventory of particlephase compounds produced from actual cooking events detected by nanospray desorption electrospray ionization-highresolution mass spectrometry (nano-DESI-HRMS) and an assessment of $\mathrm{BrC}$ chromophores specific to the biomass type used based on HPLC-PDA-HRMS analysis. In addition, we compare particle-phase constituents in cook fire smoke produced from different traditional stoves and fuels.

\section{Experimental methods}

\subsection{Field site}

This study was conducted at the SOMAARTH Demographic, Development, and Environmental Surveillance Site (Balakr- ishnan et al., 2015; Mukhopadhyay et al., 2012; Pillarisetti et al., 2014) run by the International Clinical Epidemiological Network (INCLEN) in Palwal District, located approximately $80 \mathrm{~km}$ south of New Delhi. SOMAARTH covers 51 villages across three administrative blocks, with an approximate population of 200000 . Palwal District has a population of approximately 1 million over $\sim 1400 \mathrm{~km}^{2} ; 39 \%$ of households in the district utilize wood as their primary cook fuel, followed by dung (25\%) and crop residues (7\%) (Census of India, 2011).

\subsection{Sample collection}

Over 34 days in August-September 2015, $\mathrm{PM}_{2.5}$ samples were collected from a kitchen in the village of Khatela, Palwal, Haryana, India. Figure 1 shows (a) the kitchen setup, and (b) the stoves (angithi and chulha) and fuels (dung and brushwood) used. The stoves and fuels were obtained locally, and traditional meals were prepared by a local cook. The cook was instructed by the experimenters to prepare a particular standard meal using the selected fuel and stove. All angithi cookstoves burned dung and were used to prepare buffalo fodder. Chulha cookstoves burned either brushwood or dung fuels and were used to prepare a traditional meal of chapati and vegetables for four people. Vegetables were cooked in a pressure cooker that rests on top of the chulha (Fig. 1b). Chapatti were cooked in the air space next to the fuel, as is typical for this area. Brushwood-angithi cook fires were never tested because this combination is not frequently used in the local households.

Figure S2.1 in the Supplement shows a diagram of sample collection. $\mathrm{PM}_{2.5}$ emissions were sampled via three-pronged probes that hung above the cookstove. Air sampling pumps (PCXR-8, SKC Inc.) created a flow of BBOA emissions through aluminum tubing during cooking events. BBOA was captured through cyclone fractionators $(2.5 \mu \mathrm{m}$ cut point, URG Corporation) and the resultant flow was taken through a stainless steel filter holder containing a PTFE filter (Teflon $\mathrm{B}$, SKC Inc., $47 \mathrm{~mm}$ ). One filter was collected for chemical analysis (Teflon B), and another filter for gravimetric analysis (Teflon A). Flows were measured via a mass flowmeter (TSI 4140) before and after each cooking event to ensure it had not varied more than $10 \%$. The pumps were turned on before cooking began so that emissions from the entire cooking event were captured and turned off when the fire was out. Stove dimensions and their distance from the probe inlets are detailed in Fig. S3.1. Prior to analysis, filters were stored in petri dish slides at $-80^{\circ} \mathrm{C}$ other than during transportation and use. This includes time at the field site (1-6h) and transportation back to the United States (24h). During these times, samples were stored at ambient temperature. 


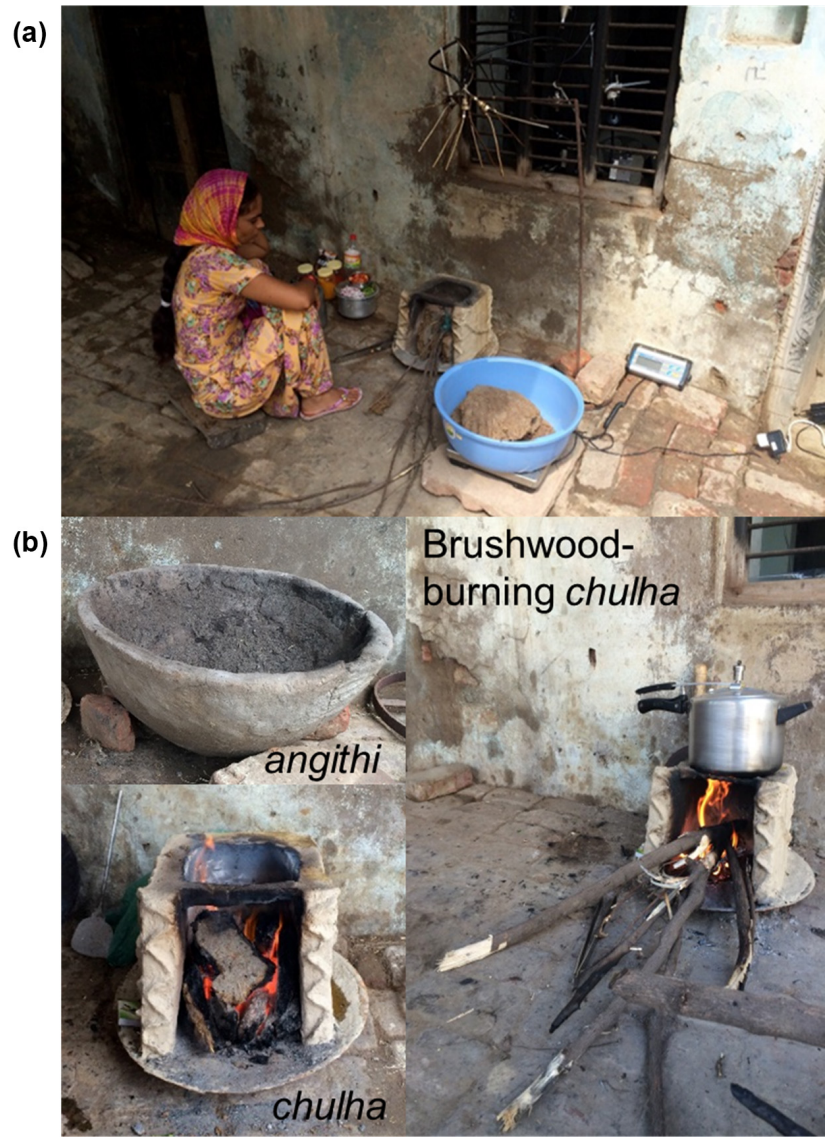

Figure 1. The field site and setup for cooking events. (a) The kitchen setup at the field site. (b) The stoves and fuels used in this study: angithi, dung-burning chulha, and brushwood-burning chulha.

\subsection{Nano-DESI-HRMS analysis}

$\mathrm{PM}_{2.5}$ collected on PTFE filters was analyzed with an LTQ-Orbitrap $^{\text {TM }}$ high-resolution mass spectrometer (ThermoFisher Scientific) equipped with a custom built nanoDESI source (Roach et al., 2010a, b). Nano-DESI consists of two electrified capillaries with a small $(<1 \mathrm{~mm})$ droplet, or solvent bridge, forming at the point of their contact. The nano-DESI solvent mixture $\left(70 \% \mathrm{CH}_{3} \mathrm{CN} / 30 \%\right.$ $\mathrm{H}_{2} \mathrm{O}$, optimized for the stability of the nano-DESI source) flows through an electrified capillary at a flow rate of $0.3-$ $1 \mu \mathrm{L} \mathrm{min}^{-1}$. The droplet is lowered to the substrate's surface, where the analyzed material is extracted by the solvent and immediately sprayed in the mass spectrometer inlet. It has been shown that the nano-DESI dissolves all extractable material on the filter surface (Roach et al., 2010a, b). To ensure the material on the filter is not depleted, the droplet is moved across the filter's surface at roughly $0.2 \mathrm{~cm} \mathrm{~min}^{-1}$. The spray voltage was $3.5 \mathrm{kV}$ and the instrument was operated in positive ion mode. The mass accuracy of the HRMS was calibrated over a wide $m / z$ range with a ThermoFisher Scien- tific standard calibration mixture. Two separate mass spectra were obtained from different portions of the filter to ensure reproducibility. Only peaks that showed up in both spectra were retained for further analysis.

Peaks with signal-to-noise ratios of greater than 3 were extracted from the time-integrated nano-DESI chromatograms using Decon2LS software. Peaks containing ${ }^{13} \mathrm{C}$ isotopes were excluded from analysis. Sample and solvent-blank mass spectra peaks were clustered with a tolerance of $0.001 \mathrm{~m} / z$ using a second-order Kendrick analysis with $\mathrm{CH}_{2}$ and $\mathrm{H}_{2}$ base units (Roach et al., 2011). The spectra were internally mass-calibrated by assigning prominent peaks of common BBOA compounds first, and fitting the observed-exact $\mathrm{m} / z$ deviation to a linear regression curve. The $m / z$ correction introduced by the internal calibration was $<0.001 \mathrm{~m} / \mathrm{z}$ units, but even at these small levels the correction helped reduce the ambiguity in the assignments of unknown peaks. We focused on analyzing peaks with $m / z<350$, as peaks above this $m / z$ value were small in abundance (on average $6 \%$ of total abundance), number of peaks ( $9 \%$ of the total number of peaks), and in many cases could not be assigned unambiguously. Exact masses were assigned using the freeware program Formula Calculator v1.1 (http: $/ /$ magnet.fsu.edu/ midas/download.html). The permitted elements and their maximal numbers of atoms were as follows: C (40), H (80), O (35), N (5), and Na (1). Peaks that could not be assigned within the described parameters had small abundances and were not pursued further. There were a few notable exceptions, namely the potassium salt peaks discussed below. Conversely, potassium-organic adducts were not observed, presumably due to the higher affinity of organic molecules to $\mathrm{Na}^{+}$compared to $\mathrm{K}^{+}$. Permitting sulfur, chloride, and phosphorus did not increase the fractions of assignable peaks, nor did it change the assignments for the peaks we report. The double-bond equivalent (DBE) values of the neutral formulas were calculated using the following equation: $\mathrm{DBE}=\mathrm{C}-\mathrm{H} / 2+\mathrm{N} / 2+1$, where $\mathrm{C}, \mathrm{H}$, and $\mathrm{N}$ correspond to the number of carbon, hydrogen, and nitrogen atoms, respectively.

\subsection{HPLC-PDA-HRMS}

The samples were further analyzed with an HPLC-PDAHRMS platform (Lin et al., 2016). To prepare the samples for analysis half of the PTFE filter was extracted overnight in a mixture of acetonitrile, dichloromethane, and hexane solvents $(2: 2: 1$ by volume, $5 \mathrm{~mL}$ total), which was empirically found to work well for extracting a broad range of BBOA compounds (Lin et al., 2017). The solutions were then filtered with polyvinyl difluoride (PVDF) filter syringes to remove insoluble particles (Millipore, Duropore, $13 \mathrm{~mm}$, $0.22 \mu \mathrm{m})$. The solutions were concentrated under $\mathrm{N}_{2}$ flow, and then diluted with water and dimethyl sulfoxide (DMSO) to a final volume around $150 \mu \mathrm{L}$. The separation was performed on a reverse-phase column (Luna C18, $2 \times 150 \mathrm{~mm}$, 
$5 \mu \mathrm{m}$ particles, $100 \AA$ A pores, Phenomenex, Inc.). The mobile phase comprised of $0.05 \%$ formic acid in LC-MS grade acetonitrile (B) and $0.05 \%$ formic acid in LC-MS grade water (A). Gradient elution was performed by the A-B mixture at a flow rate of $200 \mu \mathrm{Lmin}^{-1}: 0-3 \mathrm{~min}$ hold at $90 \% \mathrm{~A}, 3-$ 62 min linear gradient to $10 \% \mathrm{~A}, 63-75$ min hold at $10 \% \mathrm{~A}$, 76-89 min linear gradient to $0 \% \mathrm{~A}, 90-100 \mathrm{~min}$ hold at $0 \%$ A, then 101-120 min hold at $90 \%$ A. The electrospray ionization (ESI) settings were as follows: $5 \mu \mathrm{L}$ injection volume, $4.0 \mathrm{kV}$ spray potential, 35 units of sheath gas flow, 10 units of auxiliary gas flow, and 8 units of sweep gas flow. The solutions were analyzed in both positive and negative ion ESIHRMS modes.

The HPLC-PDA-HRMS data were acquired and first analyzed using Xcalibur 2.4 software (Thermo Scientific). Possible exact masses were identified by LC retention time using the open source software toolbox MZmine version 2.23 (http://mzmine.github.io/) (Pluskal et al., 2010). Formula assignments were obtained from their exact $\mathrm{m} / \mathrm{z}$ values using the Formula Calculator v1.1.

\section{5 $\mathrm{MAC}_{\text {bulk }}$ and $\mathrm{AAE}$}

Selected filter halves were extracted as described in Sect. 2.4. Absorption spectra of the extracts were collected with a dual-beam UV-Vis spectrophotometer (Shimadzu UV-2450). $\mathrm{MAC}_{\text {bulk }}$ values were calculated from the following equation:

$\operatorname{MAC}_{\text {bulk }}(\lambda)=\frac{A_{10}(\lambda) \cdot \ln (10)}{b \cdot C_{\text {mass }}}$,

where $A_{10}$ is the base-10 absorbance, $b$ is the path length of the cuvette (m), and $C_{\text {mass }}$ is the mass concentration of the extracted organic material in $\left(\mathrm{g} \mathrm{m}^{-3}\right)$. The largest uncertainty in $\mathrm{MAC}_{\text {bulk }}$ came from uncertainty in $C_{\text {mass }}$ of the extract. First, the overall mass of $\mathrm{PM}_{2.5}$ on the filter had to be estimated from another filter collected specifically for gravimetric analysis. The $\mathrm{PM}_{2.5}$ mass on the chemical analysis filter was calculated from the mass on the gravimetric analysis filter after accounting for different flows through the two filters (See Fig. S2.1). This calculation assumed the same $\mathrm{PM}_{2.5}$ collection efficiency for both filters. The particle mass distribution on the filter was assumed to be uniform, and the extraction efficiency of $\mathrm{PM}_{2.5}$ mass was estimated to be $50 \%$ by comparing the weights of filters before and after the extraction. Uncertainties incorporate flow rate measurements (10\% relative error) and extraction efficiency of $\mathrm{PM}_{2.5}$ mass (40\% relative error). Absorption angstrom exponents (AAE) were calculated for both samples by fitting the $\log \left(\mathrm{MAC}_{\text {bulk }}\right)$ vs. $\log (\lambda)$ to a linear function over the wavelength range of 300 to $700 \mathrm{~nm}$. It should be noted that there are many methods for measuring optical properties of $\mathrm{PM}_{2.5}$ particles, and the method used here provides $\mathrm{MAC}_{\text {bulk }}$ and $\mathrm{AAE}$ of extractable organic bulk material. The advantages and limitations of other methods are explained in Laskin et al. (2015).

\section{Results and discussion}

\subsection{Nano-DESI-HRMS analysis of cookstove particles}

Representative nano-DESI mass spectra from the three major types of cook fires sampled are shown in Fig. 2. It is clear from the mass spectra in Fig. 2 that the three combinations of fuel-stove types lead to distinct particle compositions. We compare the particle composition of the three major cook fire types by averaging the percentage of $\mathrm{C}_{x} \mathrm{H}_{y} \mathrm{~N}_{w}, \mathrm{C}_{x} \mathrm{H}_{y} \mathrm{O}_{z}$, and $\mathrm{C}_{x} \mathrm{H}_{y} \mathrm{O}_{z} \mathrm{~N}_{w}$ peaks in the nano-DESI spectra from multiple samples. Samples used and a summary of the following discussion is detailed in Table S1.1. The overwhelming majority of detected species by nano-DESI in dung cook fire smoke $\mathrm{PM}_{2.5}$ was attributed to $\mathrm{C}_{x} \mathrm{H}_{y} \mathrm{~N}_{w}$, compounds that contain only carbon, hydrogen, and nitrogen atoms. The average count-based fractions from $\mathrm{C}_{x} \mathrm{H}_{y} \mathrm{~N}_{w}$ species were $79.9 \% \pm 4.4$ and $82.1 \% \pm 1.0 \%$ for dung-chulha and dungangithi experiments, respectively, but only $23.8 \% \pm 7.8 \%$ for brushwood-chulha experiments. All nitrogen-containing compounds in the smoke $\mathrm{PM}_{2.5}$ come from the nitrogen content in the fuels (Coggon et al., 2016), which is likely higher for dung. Stockwell et al. (2016) reported the nitrogen content of yak dung as $1.9 \%$ by weight, while it is found to be lower for woods such as black spruce $(0.66 \%$ by weight and ponderosa pine ( $1.09 \%$ by weight) (Hatch et al., 2015). It should be noted that another study of fuels in India found the nitrogen content was roughly the same for brushwood ( $1.4 \pm 0.3 \%$ by weight) and dung $(1.4 \pm 0.1 \%$ by weight) (Gautam et al., 2016), so additional characterization of fuel composition in the future is desirable. In contrast to dung fuel, $\mathrm{PM}_{2.5}$ from brushwood cook fire smoke contained higher fractions of $\mathrm{C}_{x} \mathrm{H}_{y} \mathrm{O}_{z}$ species. Specifically, the count-based fraction assigned as $\mathrm{C}_{x} \mathrm{H}_{y} \mathrm{O}_{z}$ species was $43.1 \% \pm 14.6 \%$ in brushwood-chulha cook fires compared to only $4.1 \% \pm 0.9$ and $3.2 \% \pm 3.3 \%$ for dung-chulha and dung-angithi experiments, respectively. Many of the $\mathrm{C}_{x} \mathrm{H}_{y} \mathrm{O}_{z}$ formulas were consistent with species reported previously as lignin-pyrolysis products (Collard and Blin, 2014; Simoneit et al., 1993). Fractions of $\mathrm{C}_{x} \mathrm{H}_{y} \mathrm{O}_{z} \mathrm{~N}_{w}$ did not correlate well with fuel-stove variables and ranged from 4.1 to $34.4 \%$ in the analyzed samples.

Potassium (Hosseini et al., 2013; Sullivan et al., 2014) and levoglucosan (Jayarathne et al., 2017; Simoneit et al., 1999) are well-established flaming and smoldering BB tracers, respectively. Gas-phase chlorine species have been observed in BBOA previously (Lobert et al., 1999; Stockwell et al., 2016). Therefore it is not surprising that inorganic salt peaks containing potassium and chlorine were observed in more than half of dung cook fires (8 out of 14) and all brushwood cook fires. These peaks were pursued apart from the original analysis because the peak abundance was very large in many mass spectra, and they served as convenient internal $\mathrm{m} / \mathrm{z}$ calibration points. These mass spectra all contained $\mathrm{K}_{2} \mathrm{Cl}^{+}$as the most prominent salt peak and $\mathrm{K}_{3} \mathrm{Cl}_{2}^{+}$was also present in 


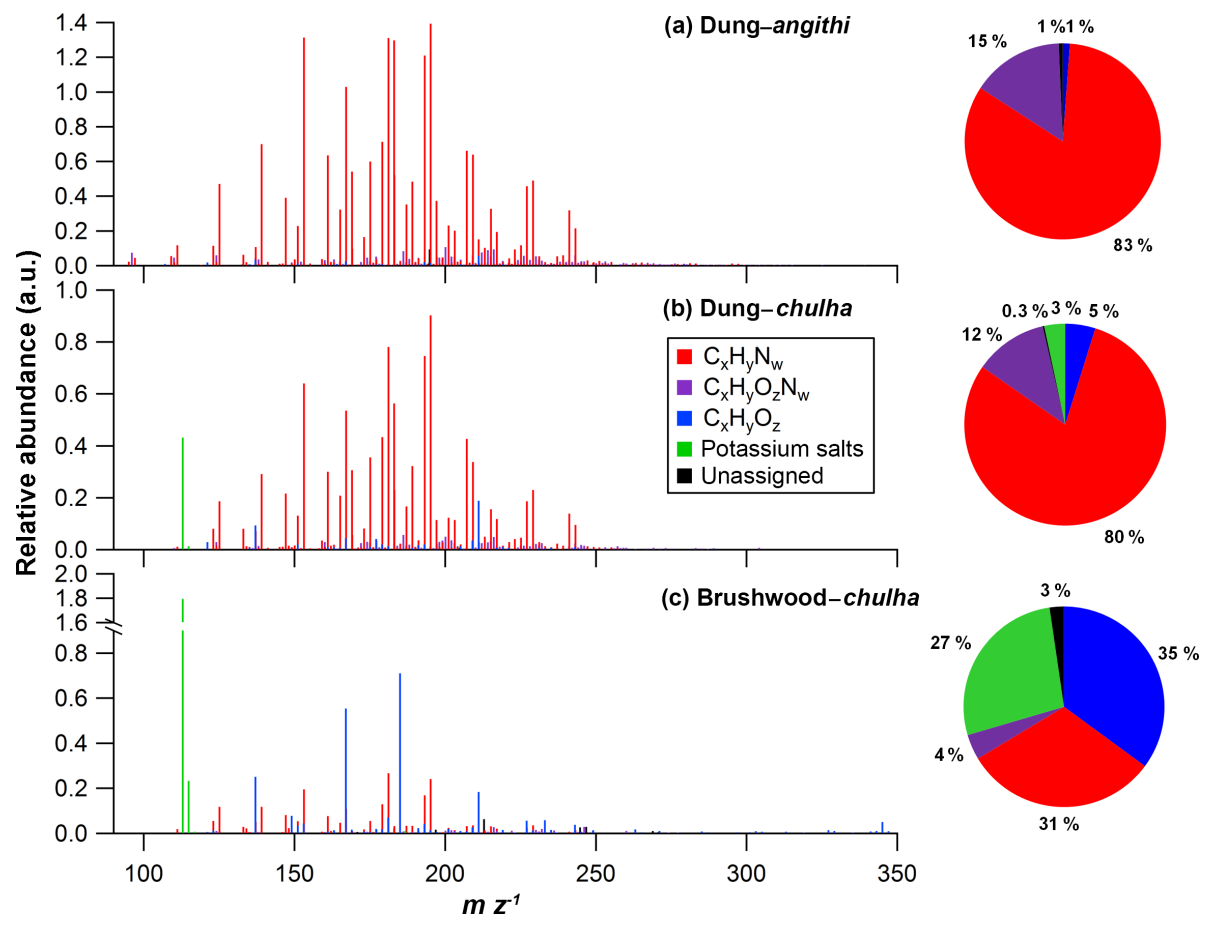

Figure 2. Representative nano-DESI mass spectra collected for (a) dung-angithi (b) dung-chulha and (c) brushwood-chulha cook fires. Relative abundance is plotted against $m / z$. Peaks are colored by their elemental makeup, $\mathrm{C}_{x} \mathrm{H}_{y} \mathrm{~N}_{w}\left(\right.$ red), $\mathrm{C}_{x} \mathrm{H}_{y} \mathrm{O}_{z} \mathrm{~N}_{w}$ (purple), $\mathrm{C}_{x} \mathrm{H}_{y} \mathrm{O}_{z}$ (blue), potassium salts (green), and unassigned (black). The pie charts illustrate the fraction of count-based, normalized peak abundance that is attributed to each elemental category.

a few mass spectra. Isotopic variants of these salts, namely with either ${ }^{37} \mathrm{Cl}$ or ${ }^{41} \mathrm{~K}$ (24 or $6.7 \%$ natural abundance) instead of ${ }^{35} \mathrm{Cl}$ or ${ }^{39} \mathrm{~K}$ (76 or $93.3 \%$ natural abundance), were also found. The resolving power of the HRMS instrument is insufficient to distinguish the isotopic shifts from $\mathrm{Cl}$ and $\mathrm{K}$ $\left(\Delta \operatorname{mass}_{37 \mathrm{Cl}-35 \mathrm{Cl}}=1.997 \mathrm{Da}, \Delta \operatorname{mass}_{41 \mathrm{~K}-39 \mathrm{~K}}=1.998 \mathrm{Da}\right)$, but one or both of the isotopes were consistently present in all mass spectra containing potassium ions. Adducts corresponding to a replacement of $\mathrm{K}$ by $\mathrm{Na}$ were also detected. The observed potassium signals may have depended not only on the potassium content of the fuel but also on the amount of flaming combustion (combustion efficiency), the specific food items cooked, or the stove material itself. Inorganic salts were observed in all chulha cook fire $\mathrm{PM}_{2.5}$ samples regardless of fuel type and were absent in all angithi cook fire $\mathrm{PM}_{2.5}$ samples. On average, chulha stoves have a higher combustion efficiency (dung-chulha $90.7 \% \pm 0.6 \%$, dung-angithi $87.5 \% \pm 1.8 \%$ ) consistent with more flaming combustion and therefore more potassium emissions. The chulha and angithi stoves produced meals for people and animal fodder, respectively. Also, the chulha was made mainly from brick with a covering of local clay, whereas the angithi was only made from clay. With the presently available data it is impossible to determine whether the potassium salts originated from flaming combustion, originated from the chulha material, or are the result of different food items cooked.
Levoglucosan was present in 3 out of 8 dung-chulha cook fires, 4 out of 6 dung-angithi cook fires, and 4 out of 11 brushwood-chulha cook fires. We expect levoglucosan to be found in BBOA from all fires, based on other studies ( $\mathrm{Ja}-$ yarathne et al., 2017), and we therefore conclude that levoglucosan peak must have been suppressed in the nano-DESI source by the more ionizable components of the mixture. By extension of the same logic, ions corresponding to other carbohydrates, and more broadly to lignin-derived $\mathrm{C}_{x} \mathrm{H}_{y} \mathrm{O}_{z}$ species, were likely suppressed by this technique, and therefore a significant fraction of BBOA constituents may be absent in this inventory. Due to the variability in observing levoglucosan we conclude that for ESI-MS studies levoglucosan serves as a marker rather than a tracer for digested biomass burning and woody biomass burning.

\subsection{Particle-phase biomass burning markers}

An inventory was compiled of compounds that were reproducibly observed in samples from three different cooking events using the same fuel-stove combination. Samples were chosen for the inventory by considering the measured fuel moisture content and meal cooked, with the goal of comparing samples from similar cook fires (see Table S1.1 for sample details). Peaks that did not appear in mass spectra of all three samples were discarded to ensure reproducibility and help filter out noise peaks from the nano-DESI source. 


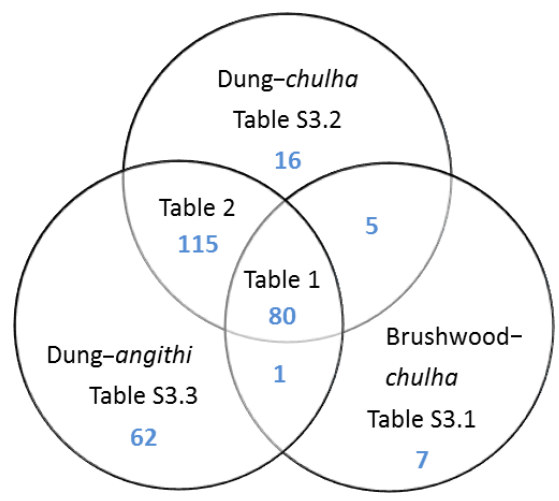

Figure 3. An overview of the particle-phase compounds inventory based on the results of molecular characterization using nano-DESIHRMS. Each area of the Venn diagram contains the bolded number of reproducibly detected formulas in blue, as well as the Table that lists peaks for each category. Merging all of the tables listed here provides a complete inventory of compounds detected in this study.

The remaining peak abundances were first normalized to the largest peak abundance, then the three mass spectra were averaged. Since the absolute peak abundances varied in individual spectra, only approximate relative abundances are reported here grouped into three logarithmic bins, denoted as LOW (<1\%), MEDIUM (1-9.9\%), and HIGH (10-100\%). This analysis was completed for the emissions from each of the three types of fuel-stove combinations studied in this work.

Figure 3 summarizes how reproducibly detected $\mathrm{PM}_{2.5}$ compounds are organized in the inventory. First, we provide a list of compounds common to the emissions from all three types of cook fires including: dung-chulha, dung-angithi, and brushwood-chulha (Sect. 3.3, Table 1). Then, we discuss compounds exclusively found in the brushwood-chulha cook fire emissions (Sect. 3.4, Table S4.1). Within Sect. 3.5 we discuss compounds unique to the dung-chulha (Table S4.2) and the dung-angithi (Table S4.3) cook fire experiments, as well as the compounds they had in common (Table 2).

The numbers of reproducibly detected formulas are shown in Fig. 3 in blue. $\mathrm{PM}_{2.5}$ from dung cook fires had a higher observed chemical complexity (i.e., had more observed peaks) than $\mathrm{PM}_{2.5}$ from brushwood cook fires. Further, there were more observed peaks in $\mathrm{PM}_{2.5}$ from dung-angithi cook fires compared to dung-chulha cook fires. There were 93 compounds reproducibly detected in the brushwood-chulha cook fire $\mathrm{PM}_{2.5}$ samples compared to 212 and 262 for dungchulha and dung-angithi cook fires, respectively. There were five compounds the chulha cook fires had in common, with two of them being the potassium salt peaks described earlier. There was one compound $\left(\mathrm{C}_{14} \mathrm{H}_{16} \mathrm{O}_{3}\right)$ shared by only dungangithi and brushwood-chulha. Because of the small number of these peaks, they will not be discussed in this paper. In the following sections, we discuss compounds that are common in all cook fires, as well as unique compounds.
Figure 4 summarizes the BBOA inventory described in more detail in Sect. 3.3-3.5, i.e., compounds common to dung-chulha, dung-angithi, brushwood-chulha cook fires; compounds found exclusively in the emissions from brushwood-chulha cook fires; and species that are unique to dung cook fires. Figure 4a compares the fraction of count-based, normalized abundance in each elemental category. $\mathrm{PM}_{2.5}$ compounds shared among all samples of this study are diverse. In terms of count-based abundance, compounds emitted from all dung-burning cook fires are largely nitrogen-containing. From Fig. $4 \mathrm{~b}$, the common compounds make up the vast majority (97\%) of detected compounds from the brushwood-chulha cook fires. Similarly for the dung cook fires, the common cook fire compounds (grey) and dung cook fire compounds (brown) make up $95 \%$ or more of the mass spectra abundance as shown in Fig. 4b. Therefore, the common compounds (Table 1 ) and dung compounds inventories (Table 2) contain the bulk of the $\mathrm{PM}_{2.5}$ species in terms of count-based abundance.

\subsection{Compounds common to dung-chulha, dung-angithi, brushwood-chulha cook fires}

Table 1 provides a complete list of eighty reproducibly detected compounds that were common to emissions from all cook fires. These common compounds make a large contribution to the mass spectra for every cook fire type (Fig. 4), with MEDIUM being the most common relative abundance given in Table 1. More than half of the abundance (59\%) was due to the nitrogen-containing compounds $\left(\mathrm{C}_{x} \mathrm{H}_{y} \mathrm{~N}_{w}\right.$ or $\mathrm{C}_{x} \mathrm{H}_{y} \mathrm{O}_{z} \mathrm{~N}_{w}$ ), as shown in Fig. 4a. ESI detection likely biases the elemental make up of smoke $\mathrm{PM}_{2.5}$, as nitrogencontaining species are more easily ionized compared to sugars and lignin-derived compounds (Laskin et al., 2010; Wan and $\mathrm{Yu}, 2006)$. Nevertheless, a large overlap in the $\mathrm{C}_{x} \mathrm{H}_{y} \mathrm{~N}_{w}$ and $\mathrm{C}_{x} \mathrm{H}_{y} \mathrm{O}_{z} \mathrm{~N}_{w}$ species was observed.

The common compounds make up a large fraction for all cook fire types. This is especially true for the sample from brushwood-chulha cook fires where their fraction is $\sim 86 \%$ in number. Many of these $\mathrm{C}_{x} \mathrm{H}_{y} \mathrm{O}_{z}$ species have elemental formulas consistent with typical lignin and cellulose-derived products such as anisaldehyde, veratraldehyde, vinylguaiacol, syringylethanone, trimethoxyphenylethanone, etc. reported previously in the literature (Laskin et al., 2009; Simoneit et al., 1993; Smith et al., 2009). These tentative molecular assignments are listed in Table 1 alongside their elemental formulas.

Approximately $20 \%$ of the common compounds (17 out of 80 formulas) have been also identified in earlier studies reporting molecular characterization of $\mathrm{PM}_{2.5}$ samples collected from burning of one or more of the following fuels: Alaskan duff, ponderosa pine duff, southern United States pine needles, or ceanothus fuels (Laskin et al., 2009; Smith et al., 2009). Many of these fuels are nonwoody and all are undigested biomass, very different kinds of biomass from 
Table 1. List of common compounds found in all $\mathrm{PM}_{2.5}$ samples regardless of fuel or stove type. Tentative molecular structure assignments are listed when the compound has previously been identified in the chemical biomass burning literature, supported by the references in the last column. Count-based, normalized peak abundances are designated LOW (<1\%), MEDIUM (1-9.9\%), and HIGH (10-100\%). All species were detected as protonated ions.

\begin{tabular}{|c|c|c|c|c|c|c|}
\hline $\begin{array}{l}\text { Observed } \\
m / z\end{array}$ & $\begin{array}{r}\text { Calculated } \\
\mathrm{m} / z\end{array}$ & $\begin{array}{l}\text { Chemical } \\
\text { formula of } \\
\text { neutral species } \\
\text { species }\end{array}$ & DBE & $\begin{array}{l}\text { Relative } \\
\text { average } \\
\text { abundance }\end{array}$ & $\begin{array}{l}\text { Tentative } \\
\text { assignment(s) }\end{array}$ & References \\
\hline 111.091 & 111.092 & $\mathrm{C}_{6} \mathrm{H}_{10} \mathrm{~N}_{2}$ & 3 & MEDIUM & & Smith et al. (2009) \\
\hline 121.064 & 121.065 & $\mathrm{C}_{8} \mathrm{H}_{8} \mathrm{O}$ & 5 & MEDIUM & & \\
\hline 123.091 & 123.092 & $\mathrm{C}_{7} \mathrm{H}_{10} \mathrm{~N}_{2}$ & 4 & MEDIUM & & \\
\hline 124.075 & 124.076 & $\mathrm{C}_{7} \mathrm{H}_{9} \mathrm{ON}$ & 4 & MEDIUM & & \\
\hline 125.107 & 125.107 & $\mathrm{C}_{7} \mathrm{H}_{12} \mathrm{~N}_{2}$ & 3 & MEDIUM & & Smith et al. (2009) \\
\hline 133.075 & 133.076 & $\mathrm{C}_{8} \mathrm{H}_{8} \mathrm{~N}_{2}$ & 6 & MEDIUM & & Laskin et al. (2009) \\
\hline 134.071 & 134.071 & $\mathrm{C}_{7} \mathrm{H}_{7} \mathrm{~N}_{3}$ & 6 & MEDIUM & & Laskin et al. (2009) \\
\hline 137.059 & 137.060 & $\mathrm{C}_{8} \mathrm{H}_{8} \mathrm{O}_{2}$ & 5 & HIGH & Anisaldehyde & $\begin{array}{l}\text { Simoneit et al. (1993); } \\
\text { Smith et al. (2009) }\end{array}$ \\
\hline 137.106 & 137.107 & $\mathrm{C}_{8} \mathrm{H}_{12} \mathrm{~N}_{2}$ & 4 & MEDIUM & & Smith et al. (2009) \\
\hline 138.090 & 138.091 & $\mathrm{C}_{8} \mathrm{H}_{11} \mathrm{ON}$ & 4 & LOW & & \\
\hline 139.122 & 139.123 & $\mathrm{C}_{8} \mathrm{H}_{14} \mathrm{~N}_{2}$ & 3 & MEDIUM & & Smith et al. (2009) \\
\hline 147.091 & 147.092 & $\mathrm{C}_{9} \mathrm{H}_{10} \mathrm{~N}_{2}$ & 6 & MEDIUM & & \\
\hline 151.074 & 151.075 & $\mathrm{C}_{9} \mathrm{H}_{10} \mathrm{O}_{2}$ & 5 & MEDIUM & Vinylguaiacol & \\
\hline 151.122 & 151.123 & $\mathrm{C}_{9} \mathrm{H}_{14} \mathrm{~N}_{2}$ & 4 & MEDIUM & & \\
\hline 153.138 & 153.139 & $\mathrm{C}_{9} \mathrm{H}_{16} \mathrm{~N}_{2}$ & 3 & HIGH & & \\
\hline 159.091 & 159.092 & $\mathrm{C}_{10} \mathrm{H}_{10} \mathrm{~N}_{2}$ & 7 & MEDIUM & & Laskin et al. (2009) \\
\hline 160.075 & 160.076 & $\mathrm{C}_{10} \mathrm{H}_{9} \mathrm{ON}$ & 7 & MEDIUM & & Laskin et al. (2009) \\
\hline 161.059 & 161.060 & $\mathrm{C}_{10} \mathrm{H}_{8} \mathrm{O}_{2}$ & 7 & MEDIUM & & \\
\hline 161.106 & 161.107 & $\mathrm{C}_{10} \mathrm{H}_{12} \mathrm{~N}_{2}$ & 6 & MEDIUM & & \\
\hline 162.102 & 162.103 & $\mathrm{C}_{9} \mathrm{H}_{11} \mathrm{~N}_{3}$ & 6 & LOW & & \\
\hline 163.074 & 163.075 & $\mathrm{C}_{10} \mathrm{H}_{10} \mathrm{O}_{2}$ & 6 & MEDIUM & & \\
\hline 165.138 & 165.139 & $\mathrm{C}_{10} \mathrm{H}_{16} \mathrm{~N}_{2}$ & 4 & MEDIUM & & \\
\hline 167.069 & 167.070 & $\mathrm{C}_{9} \mathrm{H}_{10} \mathrm{O}_{3}$ & 5 & HIGH & Veratraldehyde & Simoneit et al. (1993) \\
\hline 167.153 & 167.154 & $\mathrm{C}_{10} \mathrm{H}_{18} \mathrm{~N}_{2}$ & 3 & MEDIUM & & \\
\hline 173.106 & 173.107 & $\mathrm{C}_{11} \mathrm{H}_{12} \mathrm{~N}_{2}$ & 7 & MEDIUM & & \\
\hline 174.090 & 174.091 & $\mathrm{C}_{11} \mathrm{H}_{11} \mathrm{ON}$ & 7 & MEDIUM & & \\
\hline 175.074 & 175.075 & $\mathrm{C}_{11} \mathrm{H}_{10} \mathrm{O}_{2}$ & 7 & MEDIUM & & \\
\hline 175.122 & 175.123 & $\mathrm{C}_{11} \mathrm{H}_{14} \mathrm{~N}_{2}$ & 6 & MEDIUM & & \\
\hline 177.053 & 177.055 & $\mathrm{C}_{10} \mathrm{H}_{8} \mathrm{O}_{3}$ & 7 & MEDIUM & & \\
\hline 177.090 & 177.091 & $\mathrm{C}_{11} \mathrm{H}_{12} \mathrm{O}_{2}$ & 6 & MEDIUM & & \\
\hline 177.101 & 177.102 & $\mathrm{C}_{10} \mathrm{H}_{12} \mathrm{ON}_{2}$ & 6 & LOW & & \\
\hline 177.137 & 177.139 & $\mathrm{C}_{11} \mathrm{H}_{16} \mathrm{~N}_{2}$ & 5 & LOW & & Laskin et al. (2009) \\
\hline 179.069 & 179.070 & $\mathrm{C}_{10} \mathrm{H}_{10} \mathrm{O}_{3}$ & 6 & MEDIUM & Coniferaldehyde & \\
\hline 179.153 & 179.154 & $\mathrm{C}_{11} \mathrm{H}_{18} \mathrm{~N}_{2}$ & 4 & MEDIUM & & \\
\hline 181.169 & 181.170 & $\mathrm{C}_{11} \mathrm{H}_{20} \mathrm{~N}_{2}$ & 3 & HIGH & & \\
\hline 183.090 & 183.092 & $\mathrm{C}_{12} \mathrm{H}_{10} \mathrm{~N}_{2}$ & 9 & HIGH & & \\
\hline 183.184 & 183.186 & $\mathrm{C}_{11} \mathrm{H}_{22} \mathrm{~N}_{2}$ & 2 & MEDIUM & & \\
\hline 186.090 & 186.091 & $\mathrm{C}_{12} \mathrm{H}_{11} \mathrm{ON}$ & 8 & MEDIUM & & Laskin et al. (2009) \\
\hline 187.122 & 187.123 & $\mathrm{C}_{12} \mathrm{H}_{14} \mathrm{~N}_{2}$ & 7 & MEDIUM & & \\
\hline 188.106 & 188.107 & $\mathrm{C}_{12} \mathrm{H}_{13} \mathrm{ON}$ & 7 & MEDIUM & & \\
\hline 189.101 & 189.102 & $\mathrm{C}_{11} \mathrm{H}_{12} \mathrm{ON}_{2}$ & 7 & MEDIUM & & Laskin et al. (2009) \\
\hline 189.137 & 189.139 & $\mathrm{C}_{12} \mathrm{H}_{16} \mathrm{~N}_{2}$ & 6 & MEDIUM & & \\
\hline 191.069 & 191.070 & $\mathrm{C}_{11} \mathrm{H}_{10} \mathrm{O}_{3}$ & 7 & MEDIUM & & \\
\hline 191.117 & 191.118 & $\mathrm{C}_{11} \mathrm{H}_{14} \mathrm{ON}_{2}$ & 6 & LOW & & \\
\hline 191.153 & 191.154 & $\mathrm{C}_{12} \mathrm{H}_{18} \mathrm{~N}_{2}$ & 5 & LOW & & \\
\hline 193.085 & 193.086 & $\mathrm{C}_{11} \mathrm{H}_{12} \mathrm{O}_{3}$ & 6 & MEDIUM & & \\
\hline 193.169 & 193.170 & $\mathrm{C}_{12} \mathrm{H}_{20} \mathrm{~N}_{2}$ & 4 & MEDIUM & & \\
\hline 197.106 & 197.107 & $\mathrm{C}_{13} \mathrm{H}_{12} \mathrm{~N}_{2}$ & 9 & MEDIUM & & \\
\hline
\end{tabular}


Table 1. Continued.

\begin{tabular}{|c|c|c|c|c|c|c|}
\hline $\begin{array}{l}\text { Observed } \\
m / z\end{array}$ & $\begin{array}{r}\text { Calculated } \\
m / z\end{array}$ & $\begin{array}{l}\text { Chemical } \\
\text { formula of } \\
\text { neutral species } \\
\text { species }\end{array}$ & DBE & $\begin{array}{l}\text { Relative } \\
\text { average } \\
\text { abundance }\end{array}$ & $\begin{array}{l}\text { Tentative } \\
\text { assignment(s) }\end{array}$ & References \\
\hline 199.122 & 199.123 & $\mathrm{C}_{13} \mathrm{H}_{14} \mathrm{~N}_{2}$ & 8 & LOW & & \\
\hline 200.106 & 200.107 & $\mathrm{C}_{13} \mathrm{H}_{13} \mathrm{ON}$ & 8 & MEDIUM & & \\
\hline 201.137 & 201.139 & $\mathrm{C}_{13} \mathrm{H}_{16} \mathrm{~N}_{2}$ & 7 & MEDIUM & & \\
\hline 202.085 & 202.086 & $\mathrm{C}_{12} \mathrm{H}_{11} \mathrm{O}_{2} \mathrm{~N}$ & 8 & MEDIUM & & Laskin et al. (2009) \\
\hline 203.117 & 203.118 & $\mathrm{C}_{12} \mathrm{H}_{14} \mathrm{ON}_{2}$ & 7 & MEDIUM & & \\
\hline 203.153 & 203.154 & $\mathrm{C}_{13} \mathrm{H}_{18} \mathrm{~N}_{2}$ & 6 & MEDIUM & & \\
\hline 205.085 & 205.086 & $\mathrm{C}_{12} \mathrm{H}_{12} \mathrm{O}_{3}$ & 7 & MEDIUM & & \\
\hline 207.184 & 207.186 & $\mathrm{C}_{13} \mathrm{H}_{22} \mathrm{~N}_{2}$ & 4 & MEDIUM & & \\
\hline 209.079 & 209.081 & $\mathrm{C}_{11} \mathrm{H}_{12} \mathrm{O}_{4}$ & 6 & MEDIUM & & \\
\hline 209.200 & 209.201 & $\mathrm{C}_{13} \mathrm{H}_{24} \mathrm{~N}_{2}$ & 3 & MEDIUM & & \\
\hline 211.095 & 211.096 & $\mathrm{C}_{11} \mathrm{H}_{14} \mathrm{O}_{4}$ & 5 & HIGH & $\begin{array}{l}\text { Syringylethanone/ } \\
\text { trimethoxyphenylethanone }\end{array}$ & Simoneit et al. (1993) \\
\hline 211.121 & 211.123 & $\mathrm{C}_{14} \mathrm{H}_{14} \mathrm{~N}_{2}$ & 9 & MEDIUM & & \\
\hline 213.137 & 213.139 & $\mathrm{C}_{14} \mathrm{H}_{16} \mathrm{~N}_{2}$ & 8 & MEDIUM & & Laskin et al. (2009) \\
\hline 214.121 & 214.123 & $\mathrm{C}_{14} \mathrm{H}_{15} \mathrm{ON}$ & 8 & MEDIUM & & \\
\hline 215.153 & 215.154 & $\mathrm{C}_{14} \mathrm{H}_{18} \mathrm{~N}_{2}$ & 7 & MEDIUM & & \\
\hline 216.100 & 216.102 & $\mathrm{C}_{13} \mathrm{H}_{13} \mathrm{O}_{2} \mathrm{~N}$ & 8 & MEDIUM & & \\
\hline 217.132 & 217.134 & $\mathrm{C}_{13} \mathrm{H}_{16} \mathrm{ON}_{2}$ & 7 & MEDIUM & & \\
\hline 217.168 & 217.170 & $\mathrm{C}_{14} \mathrm{H}_{20} \mathrm{~N}_{2}$ & 6 & MEDIUM & & \\
\hline 219.100 & 219.102 & $\mathrm{C}_{13} \mathrm{H}_{14} \mathrm{O}_{3}$ & 7 & MEDIUM & & \\
\hline 227.153 & 227.154 & $\mathrm{C}_{15} \mathrm{H}_{18} \mathrm{~N}_{2}$ & 8 & MEDIUM & & \\
\hline 229.132 & 229.134 & $\mathrm{C}_{14} \mathrm{H}_{16} \mathrm{ON}_{2}$ & 8 & MEDIUM & & \\
\hline 229.168 & 229.170 & $\mathrm{C}_{15} \mathrm{H}_{20} \mathrm{~N}_{2}$ & 7 & MEDIUM & & \\
\hline 230.116 & 230.118 & $\mathrm{C}_{14} \mathrm{H}_{15} \mathrm{O}_{2} \mathrm{~N}$ & 8 & MEDIUM & & \\
\hline 231.147 & 231.149 & $\mathrm{C}_{14} \mathrm{H}_{18} \mathrm{ON}_{2}$ & 7 & LOW & & \\
\hline 232.095 & 232.097 & $\mathrm{C}_{13} \mathrm{H}_{13} \mathrm{O}_{3} \mathrm{~N}$ & 8 & MEDIUM & & \\
\hline 235.095 & 235.096 & $\mathrm{C}_{13} \mathrm{H}_{14} \mathrm{O}_{4}$ & 7 & MEDIUM & & \\
\hline 241.168 & 241.170 & $\mathrm{C}_{16} \mathrm{H}_{20} \mathrm{~N}_{2}$ & 8 & MEDIUM & & \\
\hline 243.147 & 243.149 & $\mathrm{C}_{15} \mathrm{H}_{18} \mathrm{ON}_{2}$ & 8 & MEDIUM & & \\
\hline 243.184 & 243.186 & $\mathrm{C}_{16} \mathrm{H}_{22} \mathrm{~N}_{2}$ & 7 & LOW & & \\
\hline 244.131 & 244.133 & $\mathrm{C}_{15} \mathrm{H}_{17} \mathrm{O}_{2} \mathrm{~N}$ & 8 & MEDIUM & & \\
\hline 246.111 & 246.112 & $\mathrm{C}_{14} \mathrm{H}_{15} \mathrm{O}_{3} \mathrm{~N}$ & 8 & MEDIUM & & \\
\hline 249.110 & 249.112 & $\mathrm{C}_{14} \mathrm{H}_{16} \mathrm{O}_{4}$ & 7 & MEDIUM & & \\
\hline
\end{tabular}

those used as cookstove fuels in this study and in this region of India. This suggests that perhaps $20 \%$ of the compounds listed in Table 1 might be reproducibly detected in BBOA samples using ESI-MS, regardless of biomass type. The overlap is not surprising as all biomass is composed of three polymers: lignin, hemicellulose, and cellulose (Collard and Blin, 2014).

\subsection{Compounds found exclusively in the emissions from brushwood-chulha cook fires}

Table S4.1 lists the compounds observed exclusively in the samples from brushwood-chulha cook fires. Many of them correspond to lignin-derived products that have been previously identified in BBOA by gas chromatography methods, as indicated in Table S4.1 (Lee et al., 2005; Simoneit, 2002;
Simoneit et al., 1993; Smith et al., 2009). Lignin is an essential component of wood, comprising roughly a third of its dry mass (Collard and Blin, 2014; Simoneit, 2002). Lignin is generally composed of $p$-coumaryl, coniferyl, and syringyl alcohol units. During pyrolysis, the coumaryl, vanillyl, and syringyl moieties are preserved and are found in smoke. More generally, the lignin pyrolysis products found in smoke contain a benzene ring often with hydroxy and/or methoxy substituents. Based on these previous observations, and the assumption that these are lignin pyrolysis products, tentative molecular structures were assigned to $\mathrm{C}_{x} \mathrm{H}_{y} \mathrm{O}_{z}$ compounds. It is likely that some $\mathrm{C}_{x} \mathrm{H}_{y} \mathrm{O}_{z}$ molecular species specific to the emissions from the brushwood burning were not detected in this study due to their low ionization efficiency. 
(a)
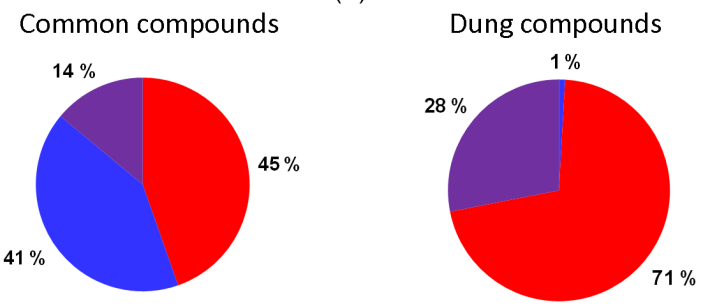

$\mathrm{C}_{\mathrm{x}} \mathrm{H}_{\mathrm{y}} \mathrm{N}_{\mathrm{w}} \quad \square \mathrm{C}_{\mathrm{x}} \mathrm{H}_{\mathrm{y}} \mathrm{O}_{\mathrm{z}} \quad \square \mathrm{C}_{\mathrm{x}} \mathrm{H}_{\mathrm{y}} \mathrm{O}_{\mathrm{z}} \mathrm{N}_{\mathrm{w}}$

(b)

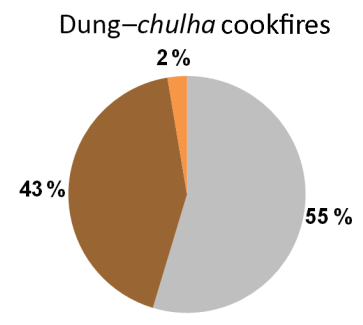

Dung-angithi cookfires

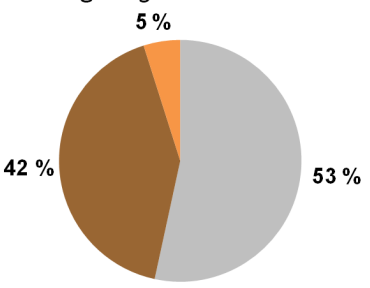

Brushwood-chulha cookfires

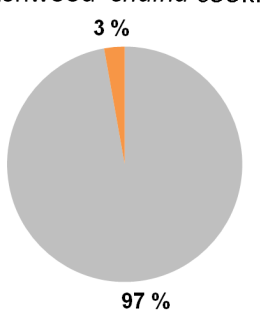

Dung Common Unique

Figure 4. A summary of the inventory in terms of the count-based, normalized peak abundances. (a) Contribution of $\mathrm{PM}_{2.5}$ compounds to each elemental formula category for those found in all cook fires and those found in all dung-burning cook fires. (b) The compounds by cookstove type classified as compounds common to all cook fires in grey, compounds common to all dung cook fires in brown, and unique compounds in orange.

\subsection{Species unique to dung smoke $\mathbf{P M}_{2.5}$}

Overall, the chemical composition of $\mathrm{PM}_{2.5}$ samples of dung-burning emissions was observed to be far more complex than the samples from the brushwood-burning cook fires. Table 2 lists the 115 compounds found exclusively and reproducibly in the dung-fueled samples. These compounds are largely $\mathrm{C}_{x} \mathrm{H}_{y} \mathrm{~N}_{w}$, as shown in Fig. 4b. Only a few of the elemental formulas, $\mathrm{C}_{8} \mathrm{H}_{16} \mathrm{~N}_{2}, \mathrm{C}_{11} \mathrm{H}_{8} \mathrm{~N}_{2}$, and $\mathrm{C}_{13} \mathrm{H}_{11} \mathrm{ON}$, have been reported previously (Laskin et al., 2009; Smith et al., 2009).

In addition to the common dung compounds listed in Table 2, there were compounds detected exclusively in the emissions from either dung-chulha cook fires (Table S4.2) or dung-angithi cook fires (Table S4.3). All of these compounds are nitrogen-containing, and none have been reported previously as BBOA compounds, to the best of our knowledge. However, in this section, we combine all compounds found in dung-burning cook fire $\mathrm{PM}_{2.5}$, presented in Tables 2, S4.2, and S4.3, and discuss their possible molecular character.

Figure 5 shows the double bond equivalent (DBE) as a function of the carbon number of compounds detected in all investigated samples. The DBE versus $\mathrm{C}$ dependence for classes of compounds with different degrees of unsaturation, including: terpenes (red), polyenes (orange), polycyclic aromatic hydrocarbons (yellow shaded) are also shown to aid the classification of the compounds observed in the $\mathrm{PM}_{2.5}$ samples. A total of 30 of the 193 formulas fall in the PAH region of the plot, suggesting that they have aromatic structures (Fig. 5a). Figure 5b compares the DBE values of the molecular components detected in the emissions exclusive to brushwood-chulha cook fires (Table S4.1) and the common compounds from all studied samples (Table 1). In general, the DBE increases with carbon number for the compounds common to all cook fires. Only 8 of the 87 compounds fall directly in the PAH region. There are more aromatic structures specific to the dung smoke compared to the compounds detected in all cook fires.

Detected nitrogen compounds with high DBE values are likely N-heterocyclic PAH compounds. Fig. 6 displays possible structures for the select detected nitrogen-containing compounds with a high DBE. Purcell et al. (2007) found that pyridinic PAH compounds were readily ionized from standard mixtures of N-heterocyclics in positive-ion ESI. This gives us more confidence in our observation of $\mathrm{C}_{13} \mathrm{H}_{9} \mathrm{~N}$, tentatively acridine, and $\mathrm{C}_{11} \mathrm{H}_{8} \mathrm{~N}_{2}$, tentatively $\beta$-carboline, which have pyridinic nitrogen atoms and likely have high ionization efficiencies. The peak abundances of these compounds are significant, with medium and high designations, respectively. $\mathrm{C}_{12} \mathrm{H}_{9} \mathrm{ON}$ cannot have a pyridinic nitrogen and is tentatively assigned as phenoxazine.

Kendrick analysis identifies homologous series of structurally related compounds that share a core formula and differ in the number $(n)$ of additional $\mathrm{CH}_{2}$ units (Hughey et al., 
Table 2. List of compounds found exclusively in the emissions from dung cook fires, regardless of stove type. The labels for the peak abundances are the same as in Table 1 . All species were detected as protonated ions unless otherwise noted.

\begin{tabular}{|c|c|c|c|c|}
\hline $\begin{array}{l}\text { Observed } \\
m / z\end{array}$ & $\begin{array}{r}\text { Calculated } \\
m / z\end{array}$ & $\begin{array}{l}\text { Chemical } \\
\text { formula of } \\
\text { neutral } \\
\text { species }\end{array}$ & DBE & $\begin{array}{l}\text { Relative } \\
\text { average } \\
\text { abundance }\end{array}$ \\
\hline 124.099 & 124.099 & $\mathrm{C}_{7} \mathrm{H}_{12} \mathrm{~N}_{2}^{*}$ & 3 & MEDIUM \\
\hline 135.080 & 135.080 & $\mathrm{C}_{9} \mathrm{H}_{10} \mathrm{O}$ & 5 & LOW \\
\hline 135.092 & 135.092 & $\mathrm{C}_{8} \mathrm{H}_{10} \mathrm{~N}_{2}$ & 5 & MEDIUM \\
\hline 136.076 & 136.076 & $\mathrm{C}_{8} \mathrm{H}_{9} \mathrm{ON}$ & 5 & LOW \\
\hline 137.071 & 137.071 & $\mathrm{C}_{7} \mathrm{H}_{8} \mathrm{ON}_{2}$ & 5 & MEDIUM \\
\hline 138.115 & 138.115 & $\mathrm{C}_{8} \mathrm{H}_{14} \mathrm{~N}_{2}^{*}$ & 3 & LOW \\
\hline 141.138 & 141.139 & $\mathrm{C}_{8} \mathrm{H}_{16} \mathrm{~N}_{2}$ & 2 & LOW \\
\hline 145.076 & 145.076 & $\mathrm{C}_{9} \mathrm{H}_{8} \mathrm{~N}_{2}$ & 7 & MEDIUM \\
\hline 146.060 & 146.060 & $\mathrm{C}_{9} \mathrm{H}_{7} \mathrm{ON}$ & 7 & MEDIUM \\
\hline 146.084 & 146.084 & $\mathrm{C}_{9} \mathrm{H}_{10} \mathrm{~N}_{2}^{*}$ & 6 & LOW \\
\hline 149.071 & 149.071 & $\mathrm{C}_{8} \mathrm{H}_{8} \mathrm{ON}_{2}$ & 6 & LOW \\
\hline 149.107 & 149.107 & $\mathrm{C}_{9} \mathrm{H}_{12} \mathrm{~N}_{2}$ & 5 & LOW \\
\hline 151.086 & 151.087 & $\mathrm{C}_{8} \mathrm{H}_{10} \mathrm{ON}_{2}$ & 5 & LOW \\
\hline 152.107 & 152.107 & $\mathrm{C}_{9} \mathrm{H}_{13} \mathrm{ON}$ & 4 & LOW \\
\hline 152.130 & 152.131 & $\mathrm{C}_{9} \mathrm{H}_{16} \mathrm{~N}_{2}^{*}$ & 3 & LOW \\
\hline 155.154 & 155.154 & $\mathrm{C}_{9} \mathrm{H}_{18} \mathrm{~N}_{2}$ & 2 & LOW \\
\hline 160.099 & 160.099 & $\mathrm{C}_{10} \mathrm{H}_{12} \mathrm{~N}_{2}^{*}$ & 6 & LOW \\
\hline 162.091 & 162.091 & $\mathrm{C}_{10} \mathrm{H}_{11} \mathrm{ON}$ & 6 & LOW \\
\hline 163.086 & 163.087 & $\mathrm{C}_{9} \mathrm{H}_{10} \mathrm{ON}_{2}$ & 6 & MEDIUM \\
\hline 163.123 & 163.123 & $\mathrm{C}_{10} \mathrm{H}_{14} \mathrm{~N}_{2}$ & 5 & MEDIUM \\
\hline 164.107 & 164.107 & $\mathrm{C}_{10} \mathrm{H}_{13} \mathrm{ON}$ & 5 & LOW \\
\hline 169.076 & 169.076 & $\mathrm{C}_{11} \mathrm{H}_{8} \mathrm{~N}_{2}$ & 9 & HIGH \\
\hline 169.170 & 169.170 & $\mathrm{C}_{10} \mathrm{H}_{20} \mathrm{~N}_{2}$ & 2 & MEDIUM \\
\hline 171.091 & 171.092 & $\mathrm{C}_{11} \mathrm{H}_{10} \mathrm{~N}_{2}$ & 8 & MEDIUM \\
\hline 172.075 & 172.076 & $\mathrm{C}_{11} \mathrm{H}_{9} \mathrm{ON}$ & 8 & MEDIUM \\
\hline 175.086 & 175.087 & $\mathrm{C}_{10} \mathrm{H}_{10} \mathrm{ON}_{2}$ & 7 & MEDIUM \\
\hline 176.070 & 176.071 & $\mathrm{C}_{10} \mathrm{H}_{9} \mathrm{O}_{2} \mathrm{~N}$ & 7 & LOW \\
\hline 176.107 & 176.107 & $\mathrm{C}_{11} \mathrm{H}_{13} \mathrm{ON}$ & 6 & LOW \\
\hline 176.118 & 176.118 & $\mathrm{C}_{10} \mathrm{H}_{13} \mathrm{~N}_{3}$ & 6 & LOW \\
\hline 178.086 & 178.086 & $\mathrm{C}_{10} \mathrm{H}_{11} \mathrm{O}_{2} \mathrm{~N}$ & 6 & LOW \\
\hline 184.075 & 184.076 & $\mathrm{C}_{12} \mathrm{H}_{9} \mathrm{ON}$ & 9 & MEDIUM \\
\hline 185.107 & 185.107 & $\mathrm{C}_{12} \mathrm{H}_{12} \mathrm{~N}_{2}$ & 8 & MEDIUM \\
\hline 187.086 & 187.087 & $\mathrm{C}_{11} \mathrm{H}_{10} \mathrm{ON}_{2}$ & 8 & MEDIUM \\
\hline 188.118 & 188.118 & $\mathrm{C}_{11} \mathrm{H}_{13} \mathrm{~N}_{3}$ & 7 & LOW \\
\hline 189.091 & 189.091 & $\mathrm{C}_{12} \mathrm{H}_{12} \mathrm{O}_{2}$ & 7 & LOW \\
\hline 190.086 & 190.086 & $\mathrm{C}_{11} \mathrm{H}_{11} \mathrm{O}_{2} \mathrm{~N}$ & 7 & MEDIUM \\
\hline 190.133 & 190.134 & $\mathrm{C}_{11} \mathrm{H}_{15} \mathrm{~N}_{3}$ & 6 & MEDIUM \\
\hline 191.081 & 191.082 & $\mathrm{C}_{10} \mathrm{H}_{10} \mathrm{O}_{2} \mathrm{~N}_{2}$ & 7 & LOW \\
\hline 192.102 & 192.102 & $\mathrm{C}_{11} \mathrm{H}_{13} \mathrm{O}_{2} \mathrm{~N}$ & 6 & LOW \\
\hline 193.133 & 193.134 & $\mathrm{C}_{11} \mathrm{H}_{16} \mathrm{ON}_{2}$ & 5 & LOW \\
\hline 195.091 & 195.092 & $\mathrm{C}_{13} \mathrm{H}_{10} \mathrm{~N}_{2}$ & 10 & MEDIUM \\
\hline 195.185 & 195.186 & $\mathrm{C}_{12} \mathrm{H}_{22} \mathrm{~N}_{2}$ & 3 & HIGH \\
\hline 197.201 & 197.201 & $\mathrm{C}_{12} \mathrm{H}_{24} \mathrm{~N}_{2}$ & 2 & MEDIUM \\
\hline 198.091 & 198.091 & $\mathrm{C}_{13} \mathrm{H}_{11} \mathrm{ON}$ & 9 & MEDIUM \\
\hline 198.102 & 198.103 & $\mathrm{C}_{12} \mathrm{H}_{11} \mathrm{~N}_{3}$ & 9 & LOW \\
\hline 199.086 & 199.087 & $\mathrm{C}_{12} \mathrm{H}_{10} \mathrm{ON}_{2}$ & 9 & MEDIUM \\
\hline 200.118 & 200.118 & $\mathrm{C}_{12} \mathrm{H}_{13} \mathrm{~N}_{3}$ & 8 & LOW \\
\hline
\end{tabular}

Table 2. Continued.

\begin{tabular}{|c|c|c|c|c|}
\hline $\begin{array}{l}\text { Observed } \\
m / z\end{array}$ & $\begin{array}{r}\text { Calculated } \\
\mathrm{m} / \mathrm{z}\end{array}$ & $\begin{array}{l}\text { Chemical } \\
\text { formula of } \\
\text { neutral } \\
\text { species }\end{array}$ & $\mathrm{DBE}$ & $\begin{array}{l}\text { Relative } \\
\text { average } \\
\text { abundance }\end{array}$ \\
\hline 201.102 & 201.102 & $\mathrm{C}_{12} \mathrm{H}_{12} \mathrm{ON}_{2}$ & 8 & MEDIUM \\
\hline 202.122 & 202.123 & $\mathrm{C}_{13} \mathrm{H}_{15} \mathrm{ON}$ & 7 & LOW \\
\hline 202.133 & 202.134 & $\mathrm{C}_{12} \mathrm{H}_{15} \mathrm{~N}_{3}$ & 7 & LOW \\
\hline 204.101 & 204.102 & $\mathrm{C}_{12} \mathrm{H}_{13} \mathrm{O}_{2} \mathrm{~N}$ & 7 & LOW \\
\hline 204.149 & 204.150 & $\mathrm{C}_{12} \mathrm{H}_{17} \mathrm{~N}_{3}$ & 6 & MEDIUM \\
\hline 205.097 & 205.097 & $\mathrm{C}_{11} \mathrm{H}_{12} \mathrm{O}_{2} \mathrm{~N}_{2}$ & 7 & LOW \\
\hline 205.133 & 205.134 & $\mathrm{C}_{12} \mathrm{H}_{16} \mathrm{ON}_{2}$ & 6 & MEDIUM \\
\hline 205.169 & 205.170 & $\mathrm{C}_{13} \mathrm{H}_{20} \mathrm{~N}_{2}$ & 5 & MEDIUM \\
\hline 206.117 & 206.118 & $\mathrm{C}_{12} \mathrm{H}_{15} \mathrm{O}_{2} \mathrm{~N}$ & 6 & LOW \\
\hline 207.112 & 207.113 & $\mathrm{C}_{11} \mathrm{H}_{14} \mathrm{O}_{2} \mathrm{~N}_{2}$ & 6 & LOW \\
\hline 207.149 & 207.149 & $\mathrm{C}_{12} \mathrm{H}_{18} \mathrm{ON}_{2}$ & 5 & LOW \\
\hline 209.107 & 209.107 & $\mathrm{C}_{14} \mathrm{H}_{12} \mathrm{~N}_{2}$ & 10 & MEDIUM \\
\hline 209.128 & 209.128 & $\mathrm{C}_{11} \mathrm{H}_{16} \mathrm{O}_{2} \mathrm{~N}_{2}$ & 5 & LOW \\
\hline 211.144 & 211.144 & $\mathrm{C}_{11} \mathrm{H}_{18} \mathrm{O}_{2} \mathrm{~N}_{2}$ & 4 & MEDIUM \\
\hline 212.106 & 212.107 & $\mathrm{C}_{14} \mathrm{H}_{13} \mathrm{ON}$ & 9 & MEDIUM \\
\hline 212.118 & 212.118 & $\mathrm{C}_{13} \mathrm{H}_{13} \mathrm{~N}_{3}$ & 9 & LOW \\
\hline 214.086 & 214.086 & $\mathrm{C}_{13} \mathrm{H}_{11} \mathrm{O}_{2} \mathrm{~N}$ & 9 & MEDIUM \\
\hline 215.117 & 215.118 & $\mathrm{C}_{13} \mathrm{H}_{14} \mathrm{ON}_{2}$ & 8 & MEDIUM \\
\hline 216.149 & 216.150 & $\mathrm{C}_{13} \mathrm{H}_{17} \mathrm{~N}_{3}$ & 7 & LOW \\
\hline 217.085 & 217.086 & $\mathrm{C}_{13} \mathrm{H}_{12} \mathrm{O}_{3}$ & 8 & LOW \\
\hline 217.097 & 217.097 & $\mathrm{C}_{12} \mathrm{H}_{12} \mathrm{O}_{2} \mathrm{~N}_{2}$ & 8 & MEDIUM \\
\hline 218.103 & 218.104 & $\mathrm{C}_{10} \mathrm{H}_{11} \mathrm{ON}_{5}$ & 8 & LOW \\
\hline 218.117 & 218.118 & $\mathrm{C}_{13} \mathrm{H}_{15} \mathrm{O}_{2} \mathrm{~N}$ & 7 & LOW \\
\hline 218.165 & 218.165 & $\mathrm{C}_{13} \mathrm{H}_{19} \mathrm{~N}_{3}$ & 6 & LOW \\
\hline 219.112 & 219.113 & $\mathrm{C}_{12} \mathrm{H}_{14} \mathrm{O}_{2} \mathrm{~N}_{2}$ & 7 & MEDIUM \\
\hline 219.149 & 219.149 & $\mathrm{C}_{13} \mathrm{H}_{18} \mathrm{ON}_{2}$ & 6 & LOW \\
\hline 219.185 & 219.186 & $\mathrm{C}_{14} \mathrm{H}_{22} \mathrm{~N}_{2}$ & 5 & MEDIUM \\
\hline 221.080 & 221.081 & $\mathrm{C}_{12} \mathrm{H}_{12} \mathrm{O}_{4}$ & 7 & LOW \\
\hline 221.128 & 221.128 & $\mathrm{C}_{12} \mathrm{H}_{16} \mathrm{O}_{2} \mathrm{~N}_{2}$ & 6 & MEDIUM \\
\hline 221.201 & 221.201 & $\mathrm{C}_{14} \mathrm{H}_{24} \mathrm{~N}_{2}$ & 4 & MEDIUM \\
\hline 223.122 & 223.123 & $\mathrm{C}_{15} \mathrm{H}_{14} \mathrm{~N}_{2}$ & 10 & MEDIUM \\
\hline 223.216 & 223.217 & $\mathrm{C}_{14} \mathrm{H}_{26} \mathrm{~N}_{2}$ & 3 & MEDIUM \\
\hline 224.107 & 224.107 & $\mathrm{C}_{15} \mathrm{H}_{13} \mathrm{ON}$ & 10 & LOW \\
\hline 225.102 & 225.102 & $\mathrm{C}_{14} \mathrm{H}_{12} \mathrm{ON}_{2}$ & 10 & MEDIUM \\
\hline 225.138 & 225.139 & $\mathrm{C}_{15} \mathrm{H}_{16} \mathrm{~N}_{2}$ & 9 & MEDIUM \\
\hline 226.122 & 226.123 & $\mathrm{C}_{15} \mathrm{H}_{15} \mathrm{ON}$ & 9 & MEDIUM \\
\hline 227.117 & 227.118 & $\mathrm{C}_{14} \mathrm{H}_{14} \mathrm{ON}_{2}$ & 9 & MEDIUM \\
\hline 228.101 & 228.102 & $\mathrm{C}_{14} \mathrm{H}_{13} \mathrm{O}_{2} \mathrm{~N}$ & 9 & MEDIUM \\
\hline 228.138 & 228.138 & $\mathrm{C}_{15} \mathrm{H}_{17} \mathrm{ON}$ & 8 & MEDIUM \\
\hline 230.164 & 230.165 & $\mathrm{C}_{14} \mathrm{H}_{19} \mathrm{~N}_{3}$ & 7 & LOW \\
\hline 231.112 & 231.113 & $\mathrm{C}_{13} \mathrm{H}_{14} \mathrm{O}_{2} \mathrm{~N}_{2}$ & 8 & MEDIUM \\
\hline 232.133 & 232.133 & $\mathrm{C}_{14} \mathrm{H}_{17} \mathrm{O}_{2} \mathrm{~N}$ & 7 & LOW \\
\hline 233.128 & 233.128 & $\mathrm{C}_{13} \mathrm{H}_{16} \mathrm{O}_{2} \mathrm{~N}_{2}$ & 7 & LOW \\
\hline 233.164 & 233.165 & $\mathrm{C}_{14} \mathrm{H}_{20} \mathrm{ON}_{2}$ & 6 & LOW \\
\hline 233.201 & 233.201 & $\mathrm{C}_{15} \mathrm{H}_{24} \mathrm{~N}_{2}$ & 5 & MEDIUM \\
\hline 235.216 & 235.217 & $\mathrm{C}_{15} \mathrm{H}_{26} \mathrm{~N}_{2}$ & 4 & MEDIUM \\
\hline 237.138 & 237.139 & $\mathrm{C}_{16} \mathrm{H}_{16} \mathrm{~N}_{2}$ & 10 & MEDIUM \\
\hline 239.117 & 239.118 & $\mathrm{C}_{15} \mathrm{H}_{14} \mathrm{ON}_{2}$ & 10 & MEDIUM \\
\hline 239.153 & 239.154 & $\mathrm{C}_{16} \mathrm{H}_{18} \mathrm{~N}_{2}$ & 9 & MEDIUM \\
\hline 241.133 & 241.134 & $\mathrm{C}_{15} \mathrm{H}_{16} \mathrm{ON}_{2}$ & 9 & MEDIUM \\
\hline
\end{tabular}


Table 2. Continued.

\begin{tabular}{lrlrl}
\hline $\begin{array}{l}\text { Observed } \\
m / z\end{array}$ & $\begin{array}{r}\text { Calculated } \\
m / z\end{array}$ & $\begin{array}{l}\text { Chemical } \\
\text { formula of } \\
\text { neutral } \\
\text { species }\end{array}$ & DBE & $\begin{array}{l}\text { Relative } \\
\text { average } \\
\text { abundance }\end{array}$ \\
\hline 242.117 & 242.118 & $\mathrm{C}_{15} \mathrm{H}_{15} \mathrm{O}_{2} \mathrm{~N}$ & 9 & LOW \\
243.112 & 243.113 & $\mathrm{C}_{14} \mathrm{H}_{14} \mathrm{O}_{2} \mathrm{~N}_{2}$ & 9 & LOW \\
244.096 & 244.097 & $\mathrm{C}_{14} \mathrm{H}_{13} \mathrm{O}_{3} \mathrm{~N}$ & 9 & LOW \\
245.128 & 245.128 & $\mathrm{C}_{14} \mathrm{H}_{16} \mathrm{O}_{2} \mathrm{~N}_{2}$ & 8 & MEDIUM \\
245.164 & 245.165 & $\mathrm{C}_{15} \mathrm{H}_{20} \mathrm{ON}_{2}$ & 7 & MEDIUM \\
247.143 & 247.144 & $\mathrm{C}_{14} \mathrm{H}_{18} \mathrm{O}_{2} \mathrm{~N}_{2}$ & 7 & LOW \\
247.216 & 247.217 & $\mathrm{C}_{16} \mathrm{H}_{26} \mathrm{~N}_{2}$ & 5 & MEDIUM \\
249.232 & 249.233 & $\mathrm{C}_{16} \mathrm{H}_{28} \mathrm{~N}_{2}$ & 4 & MEDIUM \\
251.153 & 251.154 & $\mathrm{C}_{17} \mathrm{H}_{18} \mathrm{~N}_{2}$ & 10 & LOW \\
253.133 & 253.134 & $\mathrm{C}_{16} \mathrm{H}_{16} \mathrm{ON}_{2}$ & 10 & LOW \\
255.112 & 255.113 & $\mathrm{C}_{15} \mathrm{H}_{14} \mathrm{O}_{2} \mathrm{~N}_{2}$ & 10 & LOW \\
255.148 & 255.149 & $\mathrm{C}_{16} \mathrm{H}_{18} \mathrm{ON}_{2}$ & 9 & LOW \\
255.185 & 255.186 & $\mathrm{C}_{17} \mathrm{H}_{22} \mathrm{~N}_{2}$ & 8 & LOW \\
258.112 & 258.112 & $\mathrm{C}_{15} \mathrm{H}_{15} \mathrm{O}_{3} \mathrm{~N}_{2}$ & 9 & LOW \\
259.143 & 259.144 & $\mathrm{C}_{15} \mathrm{H}_{18} \mathrm{O}_{2} \mathrm{~N}_{2}$ & 8 & LOW \\
259.180 & 259.180 & $\mathrm{C}_{16} \mathrm{H}_{22} \mathrm{ON}_{2}$ & 7 & LOW \\
269.127 & 269.128 & $\mathrm{C}_{16} \mathrm{H}_{16} \mathrm{O}_{2} \mathrm{~N}_{2}$ & 10 & LOW \\
283.143 & 283.144 & $\mathrm{C}_{17} \mathrm{H}_{18} \mathrm{O}_{2} \mathrm{~N}_{2}$ & 10 & LOW \\
\hline
\end{tabular}

* species detected as an ion-radical.

2001). 172 of the 193 detected compounds from the dungburning cook fire emissions can be grouped into 43 homologous series based on the Kendrick mass defect plot, as shown in Fig. 7. There are 15 homologous series and 5 independent formulas that make up the 61 total $\mathrm{C}_{x} \mathrm{H}_{y} \mathrm{~N}_{w}$ (red) compounds. This suggests that there are at least 20 distinct types of structures that made up the observed $\mathrm{C}_{x} \mathrm{H}_{y} \mathrm{~N}_{w}$ species. Similarly, there are 30 homologous series for $\mathrm{C}_{x} \mathrm{H}_{y} \mathrm{O}_{z} \mathrm{~N}_{w}$ (purple) formulas and $12 \mathrm{C}_{x} \mathrm{H}_{y} \mathrm{O}_{z} \mathrm{~N}_{w}$ formulas yielding at least 42 distinct types of structures for this formula category. There are no homologous series from $\mathrm{C}_{x} \mathrm{H}_{y} \mathrm{O}_{z}$ species, presumably because only a few members of this group can be detected by ESI-based methods in the $\mathrm{PM}_{2.5}$ from the dung cook fires. From this analysis, there are at least 66 unique types of structures in the 193 compounds detected from dung-burning cook fire emissions. This Kendrick analysis suggests that some of the observed $\mathrm{N}$-heterocyclic PAHs have alkyl substituents. For example, phenoxazine and $\beta$ carboline (Fig. 6) serve as the core molecules in the homologous series $\mathrm{C}_{n} \mathrm{H}_{2 n-15} \mathrm{ON}$ and $\mathrm{C}_{n} \mathrm{H}_{2 n-14} \mathrm{~N}_{2}$, respectively (Fig. 7).

\subsection{Light-absorbing properties and chromophores from cookstove emissions}

Figure 8 shows $M_{\text {ACulk }}$ values, which represent bulk absorption coefficient normalized by mass concentration of organic solvent extractable components. The $\mathrm{MAC}_{\text {bulk }}$ values were determined assuming that $50 \%$ of the particle mass (a)

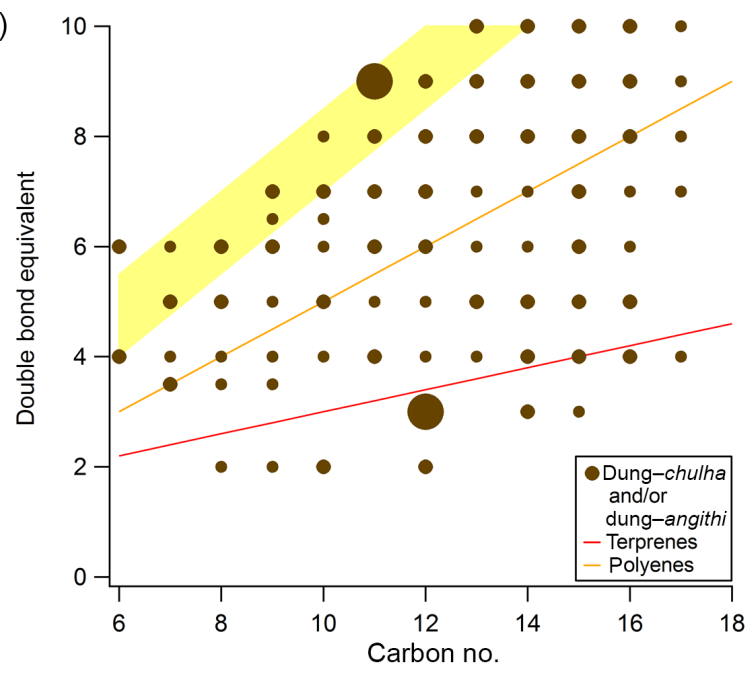

(b)

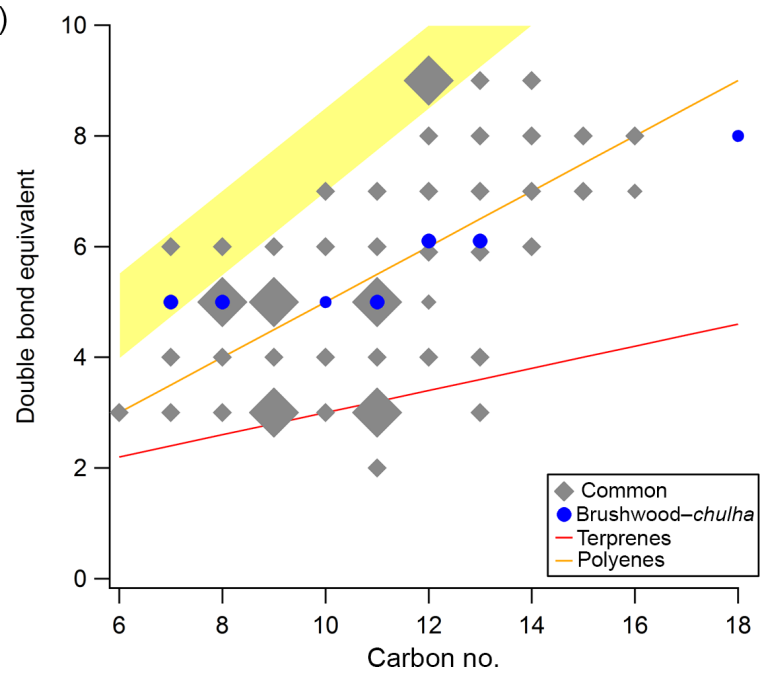

Figure 5. Double bond equivalent (DBE) as a function of the carbon number for (a) a combined set of compounds detected from all dung cook fires (brown circles) and (b) compounds that all cook fires have in common (grey diamonds as well as compounds exclusively found in brushwood (blue circles). Markers representing one or multiple species are sized by their LOW, MEDIUM, and HIGH designations. The curves illustrate theoretically where terpenes (red) and polyenes (green) would fall. Similarly, the yellowshaded region shows where PAHs would appear, including: catacondensed PAHs with 0,1 , and 2 heterocyclic nitrogen atoms and circular PAHs.

could be extracted from the filter. Error bars account for the uncertainties in the extraction efficiency (relative error $40 \%$ ), and flows during sample collection (relative error $10 \%$ ).

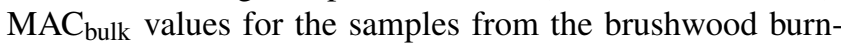
ing are roughly twice that of dung between 300 and $580 \mathrm{~nm}$. Assuming higher EC / OC for wood compared to dung as reported in Jayarathne et al. (2017), the results are consistent with Saleh et al. (2014), who predict higher effective OA absorbance for higher BC-OA ratios. 


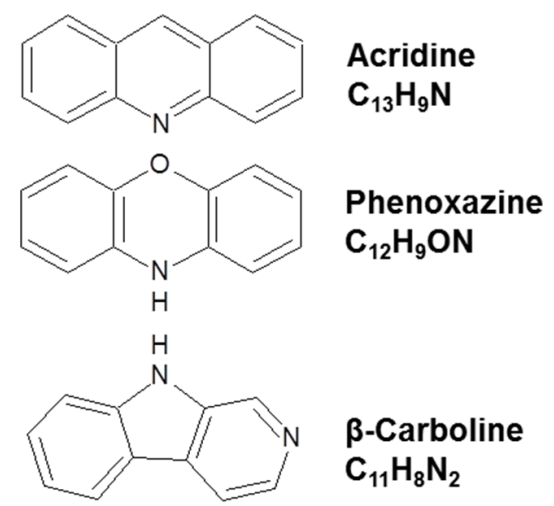

Figure 6. Possible structures of N-heterocyclic PAHs found in dung cook fire emissions. $\mathrm{C}_{13} \mathrm{H}_{9} \mathrm{~N}$ was detected reproducibly in dungchulha emissions only, while $\mathrm{C}_{12} \mathrm{H}_{9} \mathrm{ON}$ and $\mathrm{C}_{11} \mathrm{H}_{8} \mathrm{~N}_{2}$ were reproducibly detected in all dung cook fires.

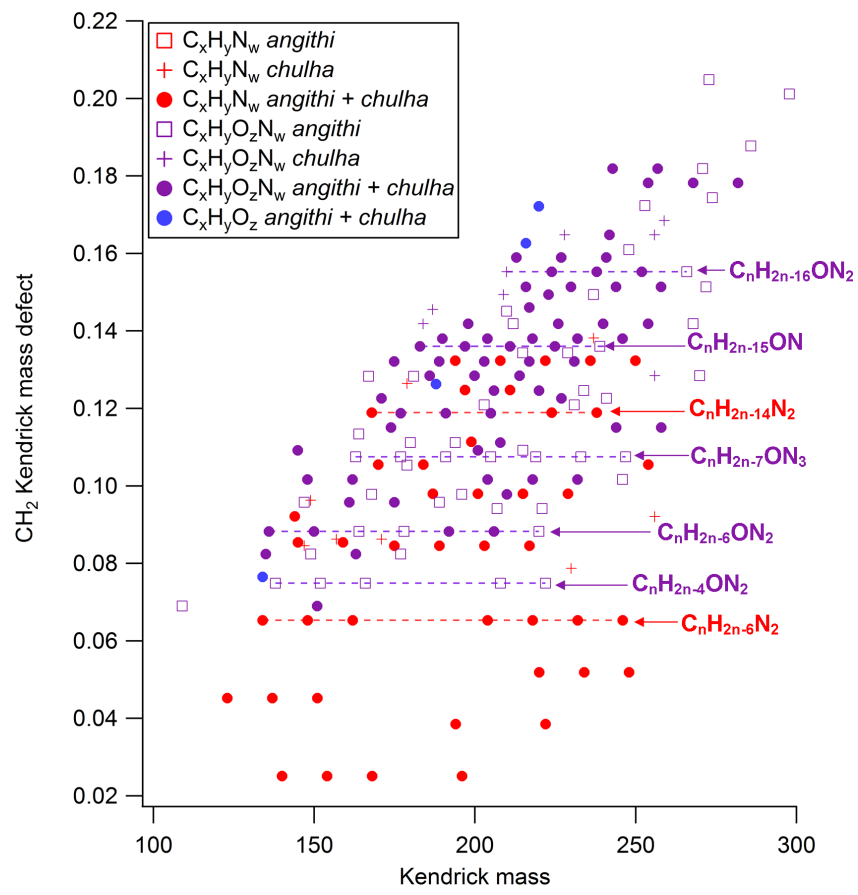

Figure 7. The $\mathrm{CH}_{2}$ Kendrick mass defect plot for compounds emitted only from dung stoves. The marker color determines the compound category for $\mathrm{C}_{x} \mathrm{H}_{y} \mathrm{~N}_{w}$ compounds (red), $\mathrm{C}_{x} \mathrm{H}_{y} \mathrm{O}_{z}$ (blue), or $\mathrm{C}_{x} \mathrm{H}_{y} \mathrm{O}_{z} \mathrm{~N}_{w}$ (purple). Marker shape indicates the stove(s) that reproducibly produced the compound: chulha and angithi $(\bullet)$, angithi $(\square)$, or chulha $(+)$. Homologous series are identified with dotted horizontal lines, suggesting that they have similar structures.

$\mathrm{MAC}_{\text {bulk }}$ values at $400 \mathrm{~nm}$ were $1.9 \pm 0.8$ and $0.9 \pm 0.4 \mathrm{~m}^{2} \mathrm{~g}^{-1}$ for the samples from brushwood-chulha and dung-chulha cook fires, respectively. For comparison, Kirchstetter and colleagues reported $\mathrm{MAC}_{\text {bulk }}$ of $2.9 \mathrm{~m}^{2} \mathrm{~g}^{-1}$ at $400 \mathrm{~nm}$ for the $\mathrm{BrC}$ in biomass smoke samples (Kirchstetter et al., 2004). Chen and Bond measured $\mathrm{MAC}_{\text {bulk }}$ values at $360 \mathrm{~nm}$ of nearly $2.0 \mathrm{~m}^{2} \mathrm{~g}^{-1}$ for methanol extracts of

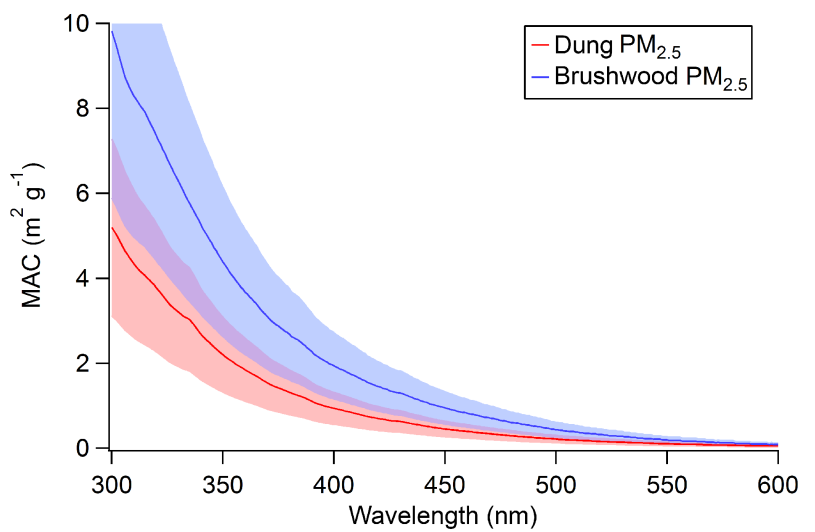

Figure 8. Comparing $\mathrm{MAC}_{\text {bulk }}\left(\mathrm{m}^{2} \mathrm{~g}^{-1}\right)$ for organic solvent extractable material from brushwood-chulha (blue) and dung-chulha (red) samples. Shaded regions represent errors due to extraction efficiency and sampling flow rates.

particles resulting from oak pyrolysis, and nearly $2.5 \mathrm{~m}^{2} \mathrm{~g}^{-1}$ for pine wood pyrolysis (Chen and Bond, 2010). Our $\mathrm{MAC}_{\text {bulk }}$ value at $360 \mathrm{~nm}$ for brushwood was larger at $3.7 \pm 1.5 \mathrm{~m}^{2} \mathrm{~g}^{-1}$, possibly due to a more efficient extraction of a broader range of chromophores by the utilized solvents. The pyrolysis temperature and wood composition could also contribute to this difference. Our MAC bulk value at $360 \mathrm{~nm}$ for dung was lower compared to our brushwood sample at $1.8 \pm 0.8 \mathrm{~m}^{2} \mathrm{~g}^{-1}$. This could be a combined result of the likely lower pyrolysis temperature and difference in the biomass composition (Chen and Bond, 2010).

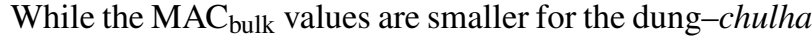
cook fires, the $\mathrm{PM}_{2.5}$ emission factors (a detailed analysis of the emission factors will be reported in a follow up paper) are more than a factor of 2.5 higher for dung-chulha fires $\left(21.1 \pm 4.2 \mathrm{~g} \mathrm{~kg}^{-1}\right.$ fuel) compared to brushwood-chulha fires $\left(7.3 \pm 1.8 \mathrm{~g} \mathrm{~kg}^{-1}\right.$ fuel). The product $\mathrm{MAC}_{\text {bulk }} \times \mathrm{EF}$ can be used to estimate the contribution of smoke to the absorption coefficient for the per unit mass of the fuel burned. At $400 \mathrm{~nm}, \quad \mathrm{MAC}_{\text {bulk }} \times \mathrm{EF}=19.0 \pm 9.2 \mathrm{~m}^{2} \mathrm{~kg}^{-1}$ fuel and $13.9 \pm 6.8 \mathrm{~m}^{2} \mathrm{~kg}^{-1}$ fuel for dung-chulha fires and brushwood-chulha fires, respectively. For particles that are small in diameter relative to the wavelength, $\mathrm{MAC}_{\text {aerosol }} \sim 0.7 \times \mathrm{MAC}_{\text {bulk }}$ (Laskin et al., 2015). Based on this we can estimate $\mathrm{MAC}_{\text {aerosol }} \times \mathrm{EF}=$ $13.3 \pm 6.5 \mathrm{~m}^{2} \mathrm{~kg}^{-1}$ fuel and $9.7 \pm 4.8 \mathrm{~m}^{2} \mathrm{~kg}^{-1}$ fuel for dung-chulha fires and brushwood-chulha fires, respectively. The values are somewhat higher than the "EF $B_{a b s} 405$ just BrC" values reported by Stockwell et al. (2016) at $405 \mathrm{~nm}$, which were $8.40 \mathrm{~m}^{2} \mathrm{~kg}^{-1}$ fuel and $5.43 \mathrm{~m}^{2} \mathrm{~kg}^{-1}$ fuel for hardwood cooking smoke and dung cooking smoke, respectively. However, both the present results and the data from Stockwell et al. (2016) show that the dung-based and wood-based fuels make comparable contributions to the absorption coefficient of the smoke for same amount of fuel consumed. 

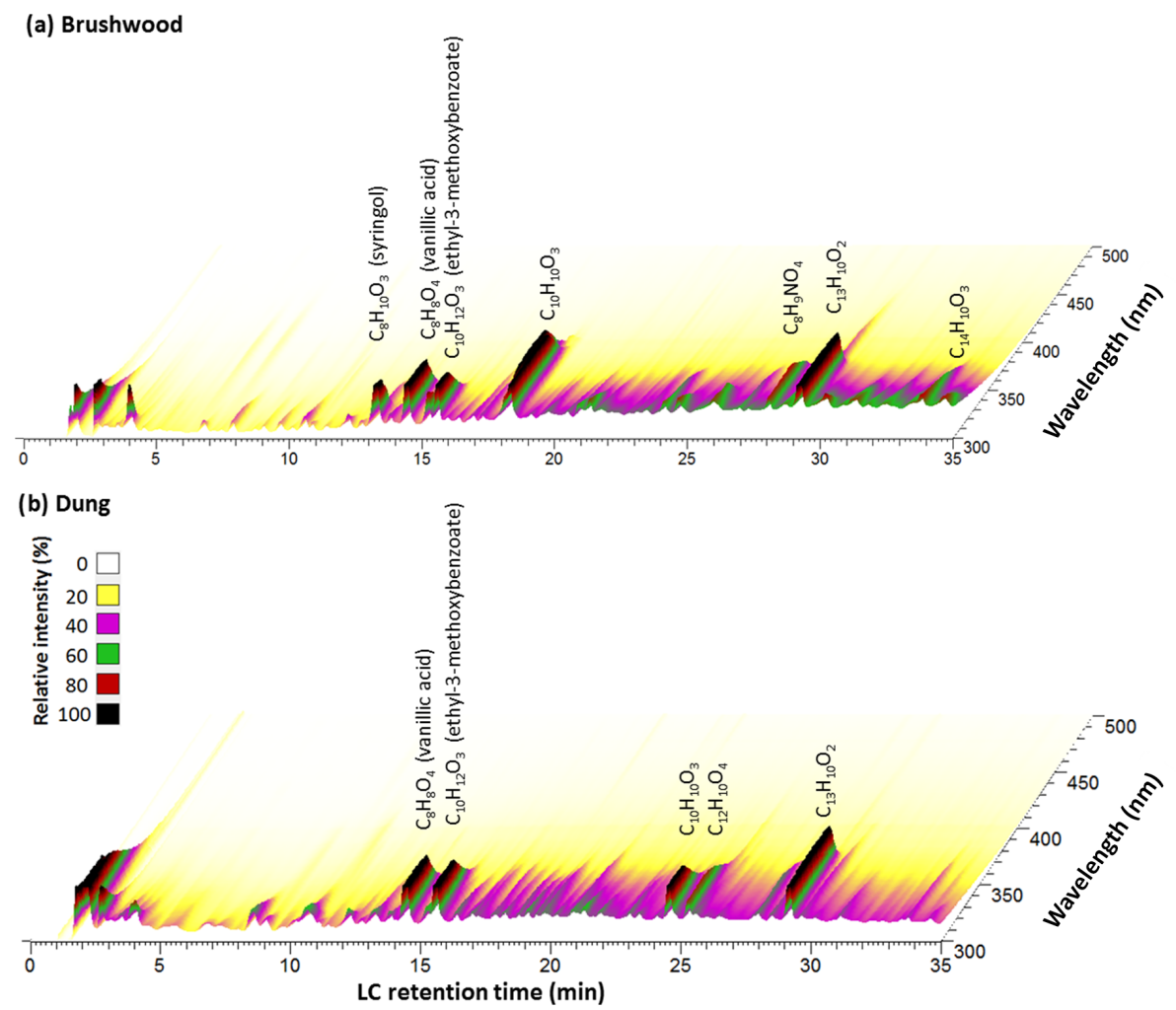

Figure 9. HPLC-PDA chromatogram showing BrC chromophores detected in the emission samples from (a) brushwood and (b) dung cook fires. Highly absorbing molecules and their corresponding PDA retention times are given above the peak.

The AAE values for the extractable organics in brushwood and dung samples are 7.5 and 6.8, respectively. Our brushwood AAE fits into the lower end of the AAE range for extracted organics presented in Chen and Bond, 6.9 to 11.4 (Chen and Bond, 2010). Typical AAE values cited in the literature for $\mathrm{BrC}$ in BBOA are in a range of 2-11 (Kirchstetter et al., 2004; Laskin et al., 2015). The AAE of the entire cooking aerosol (with the contribution of the insoluble BC included) should be lower. For example, Stockwell et al. (2016) reported in situ measurements of AAE of 3.01 and 4.63 for brushwood and dung cooking particles, respectively.

We now focus on identifying selected chromophores that contribute to the high $\mathrm{MAC}_{\text {bulk }}$ we observe for cookstove $\mathrm{PM}_{2.5}$. Two cook fires using dung and brushwood fuels were selected for a more detailed analysis of the light-absorbing molecules (BrC chromophores). The dung cook fire utilized an angithi cookstove to prepare buffalo fodder. The brushwood cook fire was used to prepare a traditional meal of rice and lentils with a chulha. More detailed sample information is provided in Table S1.3. The samples were analyzed using HPLC-PDA-ESI-HRMS platform following the methods described elsewhere (Lin et al., 2015, 2016, 2017). The identified chromophores and their PDA chromatograms are illustrated in Fig. 9, and the retention times and peaks in the absorption spectra are listed in Tables 3 and 4 for the emissions from brushwood and dung cook fires, respectively.
The BrC chromophores for both brushwood and dung samples are largely $\mathrm{C}_{x} \mathrm{H}_{y} \mathrm{O}_{z}$ compounds (Tables 3 and 4). We conclude that lignin-derived $\mathrm{BrC}$ chromophores account for the majority of the extracted light-absorbing compounds in both samples. We also found a few nitrogen-containing BrC chromophores (e.g., $\mathrm{C}_{9} \mathrm{H}_{7} \mathrm{NO}_{2}$ and $\mathrm{C}_{8} \mathrm{H}_{9} \mathrm{NO}_{3}$ ) in both the brushwood and dung samples. The woody and digested biomasses shared three strongly absorbing chromophores, $\mathrm{C}_{8} \mathrm{H}_{8} \mathrm{O}_{4}$ (tentatively vanillic acid), $\mathrm{C}_{10} \mathrm{H}_{12} \mathrm{O}_{3}$ (tentatively ethyl methoxybenzoate), and $\mathrm{C}_{13} \mathrm{H}_{10} \mathrm{O}_{2}$, as well as comparably weaker-absorbing chromophores.

$\mathrm{C}_{10} \mathrm{H}_{10} \mathrm{O}_{3}$ is another strong absorber of near-UV radiation that was found in both samples. In the brushwood-derived $\mathrm{PM}_{2.5}, \mathrm{C}_{10} \mathrm{H}_{10} \mathrm{O}_{3}$ elutes at $18.3 \mathrm{~min}\left(\lambda_{\max }=337 \mathrm{~nm}\right)$, while in the dung smoke sample, it is not observed until $24.5 \mathrm{~min}$ $\left(\lambda_{\max }=299,308 \mathrm{~nm}\right)$. These are clearly different chromophores with the same chemical formula, possibly coniferaldehyde and methoxycinnamic acid. $\mathrm{C}_{9} \mathrm{H}_{8} \mathrm{O}_{3}$ is a similar case, in which the same chemical formula appears at different retention times in the selected ion chromatograms (SICs) for brushwood- and dung-derived $\mathrm{PM}_{2.5}$. In the brushwoodderived $\mathrm{PM}_{2.5}$ sample, $\mathrm{C}_{9} \mathrm{H}_{8} \mathrm{O}_{3}$ coelutes with $\mathrm{C}_{9} \mathrm{H}_{7} \mathrm{NO}_{2}$ at 17.3 min (Table 3). In the dung $\mathrm{PM}_{2.5}$ sample $\mathrm{C}_{9} \mathrm{H}_{8} \mathrm{O}_{3}$ coelutes with $\mathrm{C}_{8} \mathrm{H}_{8} \mathrm{O}_{4}$ and $\mathrm{C}_{9} \mathrm{H}_{10} \mathrm{O}_{4}$ at 14.4 min (Table 4). The $\mathrm{C}_{9} \mathrm{H}_{8} \mathrm{O}_{3}$ formula could correspond to coumaric acid for either retention time. Because the compound coelutes with 
Table 3. The list of retention times, absorption peak maxima, and chemical formulas of the BrC chromophores detected in the brushwood smoke sample. Tentative assignments are given based on compounds previously identified in the lignin pyrolysis literature.

\begin{tabular}{|c|c|c|c|c|}
\hline $\begin{array}{l}\text { LC retention } \\
\text { time (min) }\end{array}$ & $\begin{array}{r}\lambda \max \\
(\mathrm{nm})\end{array}$ & $\begin{array}{r}\text { Nominal molecular } \\
\text { weight (amu) }\end{array}$ & $\begin{array}{l}\text { Chemical } \\
\text { formula(s) }\end{array}$ & $\begin{array}{l}\text { Tentative } \\
\text { assignment }\end{array}$ \\
\hline 6.26 & 383 & 192 & $\mathrm{C}_{9} \mathrm{H}_{8} \mathrm{~N}_{2} \mathrm{O}_{3}$ & \\
\hline 7.15 & 392 & 141 & $\mathrm{C}_{7} \mathrm{H}_{8} \mathrm{O}_{3}$ & \\
\hline 10.55 & 305 & 183 & $\mathrm{C}_{9} \mathrm{H}_{10} \mathrm{O}_{4}$ & Homovanillic acid/syringealdehyde \\
\hline 13.29 & 265 & 155 & $\mathrm{C}_{8} \mathrm{H}_{10} \mathrm{O}_{3}$ & Syringol \\
\hline \multirow[t]{2}{*}{14.44} & 305 & 169 & $\mathrm{C}_{8} \mathrm{H}_{8} \mathrm{O}_{4}$ & Vanillic acid \\
\hline & & 183 & $\mathrm{C}_{9} \mathrm{H}_{10} \mathrm{O}_{4}$ & Homovanillic acid/syringealdehyde \\
\hline \multirow[t]{2}{*}{15.57} & 299 & 181 & $\mathrm{C}_{10} \mathrm{H}_{12} \mathrm{O}_{3}$ & Ethyl-3-methoxybenzoate \\
\hline & & 167 & $\mathrm{C}_{9} \mathrm{H}_{10} \mathrm{O}_{3}$ & Veratraldehyde \\
\hline 16.95 & 313,334 & 186 & $\mathrm{C}_{11} \mathrm{H}_{7} \mathrm{NO}_{2}$ & \\
\hline \multirow[t]{2}{*}{17.25} & 331 & 165 & $\mathrm{C}_{9} \mathrm{H}_{8} \mathrm{O}_{3}$ & \\
\hline & & 162 & $\mathrm{C}_{9} \mathrm{H}_{7} \mathrm{NO}_{2}$ & \\
\hline 18.13 & 341 & 209 & $\mathrm{C}_{11} \mathrm{H}_{12} \mathrm{O}_{4}$ & \\
\hline 18.32 & 229,337 & 179 & $\mathrm{C}_{10} \mathrm{H}_{10} \mathrm{O}_{3}$ & \\
\hline 19.78 & 305,330 & 194 & $\mathrm{C}_{10} \mathrm{H}_{10} \mathrm{O}_{4}$ & Ferulic acid \\
\hline 24.11 & 290,330 & 259 & $\mathrm{C}_{15} \mathrm{H}_{14} \mathrm{O}_{4}$ & \\
\hline 28.07 & 334 & 184 & $\mathrm{C}_{8} \mathrm{H}_{9} \mathrm{NO}_{4}$ & \\
\hline \multirow[t]{2}{*}{29.24} & 330 & 198 & $\mathrm{C}_{13} \mathrm{H}_{10} \mathrm{O}_{2}$ & \\
\hline & & 230 & $\mathrm{C}_{13} \mathrm{H}_{10} \mathrm{O}_{4}$ & \\
\hline 33.81 & 340 & 227 & $\mathrm{C}_{14} \mathrm{H}_{10} \mathrm{O}_{3}$ & \\
\hline
\end{tabular}

Table 4. The list of retention times, absorption peak maxima, and chemical formulas of the BrC chromophores detected in the dung smoke sample. Tentative assignments are given based on compounds previously identified in the lignin pyrolysis literature.

\begin{tabular}{lrrll}
\hline $\begin{array}{l}\text { LC retention } \\
\text { time (min) }\end{array}$ & $\begin{array}{r}\lambda_{\max } \\
(\mathrm{nm})\end{array}$ & $\begin{array}{r}\text { Nominal molecular } \\
\text { weight }(\mathrm{amu})\end{array}$ & $\begin{array}{l}\text { Chemical } \\
\text { formula(s) }\end{array}$ & $\begin{array}{l}\text { Tentative } \\
\text { assignment }\end{array}$ \\
\hline 8.5 & 295 & 167 & $\mathrm{C}_{8} \mathrm{H}_{9} \mathrm{NO}_{3}$ & \\
9.09 & 282,300 & 166 & $\mathrm{C}_{9} \mathrm{H}_{10} \mathrm{O}_{3}$ & \\
& & 168 & $\mathrm{C}_{8} \mathrm{H}_{8} \mathrm{O}_{4}$ & \\
10.59 & $252,289,393$ & 182 & $\mathrm{C}_{9} \mathrm{H}_{10} \mathrm{O}_{4}$ & Homovanillic acid/syringealdehyde \\
12.22 & 282 & 122 & $\mathrm{C}_{7} \mathrm{H}_{6} \mathrm{O}_{2}$ & Benzoic acid \\
14.44 & 306 & 168 & $\mathrm{C}_{8} \mathrm{H}_{8} \mathrm{O}_{4}$ & Vanillic acid \\
& & 182 & $\mathrm{C}_{9} \mathrm{H}_{10} \mathrm{O}_{4}$ & Homovanillic acid/syringealdehyde \\
& & 164 & $\mathrm{C}_{9} \mathrm{H}_{8} \mathrm{O}_{3}$ & \\
15.57 & 300 & 174 & $\mathrm{C}_{10} \mathrm{H}_{12} \mathrm{O}_{3}$ & Ethyl-3-methoxybenzoate \\
& & 166 & $\mathrm{C}_{9} \mathrm{H}_{10} \mathrm{O}_{3}$ & Veratraldehyde \\
16.35 & 286 & 174 & $\mathrm{C}_{11} \mathrm{H}_{10} \mathrm{O}_{2}$ & \\
18.28 & 162 & $\mathrm{C}_{10} \mathrm{H}_{10} \mathrm{O}_{2}$ & \\
19.5 & $290,330^{*}$ & 220 & $\mathrm{C}_{12} \mathrm{H}_{12} \mathrm{O}_{4}$ & \\
19.72 & $323^{*}$ & 194 & $\mathrm{C}_{10} \mathrm{H}_{10} \mathrm{O}_{4}$ & Ferulic acid \\
20.85 & $331^{*}$ & 188 & $\mathrm{C}_{12} \mathrm{H}_{12} \mathrm{O}_{2}$ & \\
24.54 & $352^{*}$ & 178 & $\mathrm{C}_{10} \mathrm{H}_{10} \mathrm{O}_{3}$ & \\
25.28 & 299,308 & 218 & $\mathrm{C}_{12} \mathrm{H}_{10} \mathrm{O}_{4}$ & \\
29.17 & 290,320 & 198 & $\mathrm{C}_{13} \mathrm{H}_{10} \mathrm{O}_{2}$ & \\
& 332 & 230 & $\mathrm{C}_{13} \mathrm{H}_{10} \mathrm{O}_{4}$ & \\
29.6 & & 213 & $\mathrm{C}_{13} \mathrm{H}_{9} \mathrm{O}_{3}$ & \\
\hline
\end{tabular}

* signifies a shoulder, rather than a clear peak 
other potential chromophores, we refrained from assigning a proposed structure to the chemical formula.

There were light-absorbing molecules specific to brushwood-derived $\mathrm{PM}_{2.5}$ (Table 3) that could account for higher $\mathrm{MAC}_{\mathrm{bulk}}$ values compared to the dung-derived $\mathrm{PM}_{2.5} \cdot \mathrm{C}_{8} \mathrm{H}_{9} \mathrm{NO}_{4}$ is a possible nitroaromatic compound with its absorbance peaking around $335 \mathrm{~nm} . \mathrm{C}_{8} \mathrm{H}_{10} \mathrm{O}_{3}$, tentatively syringol, is closely related to syringic acid, a lignin monomer. The formula was also detected in the dung-derived $\mathrm{PM}_{2.5}$ sample, but the absorption was lower by approximately a factor of 20 is therefore not considered a main chromophore.

There were strongly absorbing $\mathrm{BrC}$ chromophores in the $\mathrm{PM}_{2.5}$ generated by burning dung fuel that eluted in the first couple of min of the sample run (See Fig. 9b). These early eluting chromophores were likely polar compounds that were not retained well by the column and thus could not be assigned. The challenges with assigning co-eluting chromophores in BBOA were previously noted by Lin et al. (2016). For both $\mathrm{PM}_{2.5}$ samples, most of the chromophores eluted in the first $30 \mathrm{~min}$ of the run shown in Fig. 9. Compounds eluting in the range of 30 to 60 min were also satisfactorily separated, but these were weakly absorbing. The nonpolar PAH compounds absorbing in UV-Vis range are not ionized by the ESI source and subsequently not detected by HRMS (Lin et al., 2016). It is possible that additional light-absorbing molecules essential to dung smoke were strongly retained by the column and eluted after $60 \mathrm{~min}$.

Absorption spectra recorded in tandem with the mass spectra provide additional constraints on the assignments. For example, at 15.6 min $\mathrm{C}_{10} \mathrm{H}_{12} \mathrm{O}_{3}$ and $\mathrm{C}_{9} \mathrm{H}_{10} \mathrm{O}_{3}$ coeluted in both BBOA samples. These compounds were given the tentative assignments of ethyl-3-methoxybenzoate and veratraldehyde, respectively. The UV-Vis absorbance of ethyl3-methoxybenzoate shown in Fig. 10 provides a reasonable match for the recorded PDA spectra for both samples at a retention time of $15.6 \mathrm{~min}$. Veratraldehyde, which is derived broadly from lignin, has an absorption spectrum that peaks at $308 \mathrm{~nm}$ in aqueous solution (Anastasio et al., 1997). Therefore, both ethyl-3-methoxybenzoate and veratraldehyde contribute to the spectrum observed by the PDA detector, although they cannot be completely separated with this HPLC protocol.

For many formulas, multiple structural isomers were observed in SICs with peaks appearing at more than one retention time. This behavior has been observed for other types of BBOA samples, described in Lin et al. (2016), and is inherent to lignin's nature, such that a single $\mathrm{C}_{x} \mathrm{H}_{y} \mathrm{O}_{z}$ chemical formula can correspond to multiple possible structural isomers. There are several cases in which chemical formulas show up multiple times in Tables 3-4. An example from the brushwood $\mathrm{PM}_{2.5}$ (Table 3) is $\mathrm{C}_{9} \mathrm{H}_{10} \mathrm{O}_{4}$ which elutes at 10.6 and 14.4 min. $\mathrm{C}_{9} \mathrm{H}_{10} \mathrm{O}_{4}$ has been previously found in lignin pyrolysis $\mathrm{BBOA}$ in the forms of homovanillic acid and syringealdehyde (Simoneit et al., 1993). $\mathrm{C}_{8} \mathrm{H}_{8} \mathrm{O}_{4}$ and

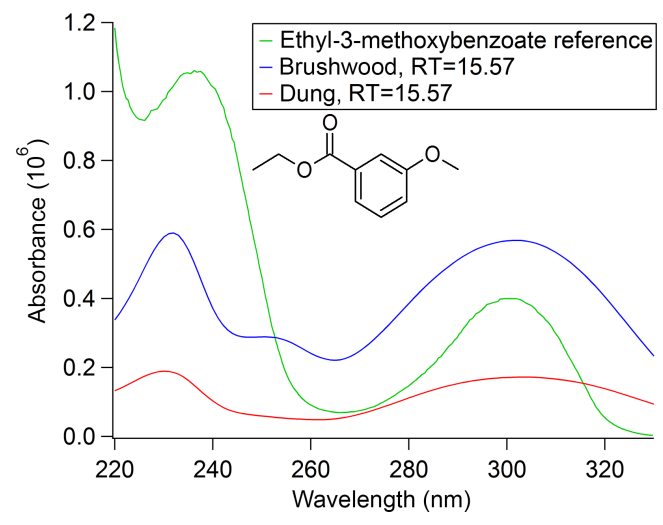

Figure 10. UV-Vis absorption spectra from the PDA analysis of cookstove BBOA samples. The blue and red curves represent the background-subtracted absorbance at retention time of $15.57 \mathrm{~min}$ for brushwood-derived $\mathrm{PM}_{2.5}$ and dung-derived $\mathrm{PM}_{2.5}$, respectively. The reference absorption spectrum of ethyl-3methoxybenzoate (green) was reproduced from the NIST Chemistry WebBook database (Talrose et al., 2017). The structure of ethyl-3methoxybenzoate is pictured.

$\mathrm{C}_{9} \mathrm{H}_{10} \mathrm{O}_{3}$ are additional examples of the similar occurrence in the sample of dung-derived $\mathrm{PM}_{2.5}$, as they both appear twice in the SICs as shown in Table 4. One peak corresponding to $\mathrm{C}_{8} \mathrm{H}_{8} \mathrm{O}_{4}$ is very likely to be vanillic acid ( $\mathrm{Si}-$ moneit, 2002; Simoneit et al., 1993). $\mathrm{C}_{9} \mathrm{H}_{10} \mathrm{O}_{3}$ could be either veratraledehyde or homoanisic acid, both have been observed from lignin pyrolysis (Simoneit et al., 1993). Collectively, these results indicate that many of the lignin-like chromophores have multiple structural isomers, some of which have likely been observed before (Simoneit, 2002; Simoneit et al., 1993).

\section{Summary}

Molecular analysis of $\mathrm{PM}_{2.5}$ emissions from three types of fuel-stove combinations showed that the observed chemical complexity of particle composition increased in the following order: brushwood-chulha, dung-chulha, dung-angithi. The compounds accounting for the additional complexity in dung-derived emissions were mostly $\mathrm{C}_{x} \mathrm{H}_{y} \mathrm{O}_{z} \mathrm{~N}_{w}$ and $\mathrm{C}_{x} \mathrm{H}_{y} \mathrm{~N}_{w}$ species, which have not been identified before in cookstove BBOA. A substantial portion of the compounds specific to dung cook fires appeared to be aromatic based on their degree of unsaturation. The $\mathrm{CH}_{2}$-Kendrick analysis of the nitrogen-containing species from dung cook fires indicated that many may be structurally related by substitution with alkyl chains of variable length.

The estimated $\mathrm{MAC}_{\text {bulk }}$ values for the $\mathrm{PM}_{2.5}$ emissions samples from brushwood-chulha and dung-chulha cook fires were comparable in magnitude and wavelength dependence to the values previously observed for BBOA samples. While the $\mathrm{MAC}_{\text {bulk }}$ values for the brushwood-derived 
BBOA were higher than those for the dung-derived BBOA, the particle emission factors had the opposite relationship. Therefore, per unit mass of burned fuel, the dung and brushwood fueled cookstoves may have comparable contribution to the overall light absorption. A set of $\mathrm{PM}_{2.5}$ samples from brushwood-chulha and dung-chulha cook fires was analyzed using HPLC-PDA-HRMS to identify BrC chromophores. The vast majority of chromophores observed for both fuel types were lignin-like $\mathrm{C}_{x} \mathrm{H}_{y} \mathrm{O}_{z}$ compounds. There were three retention times at which strongly absorbing chromophores eluted for both samples: $\mathrm{C}_{8} \mathrm{H}_{8} \mathrm{O}_{4}$ (vanillic acid), $\mathrm{C}_{10} \mathrm{H}_{12} \mathrm{O}_{3}$ (methoxybenzoate), and $\mathrm{C}_{13} \mathrm{H}_{10} \mathrm{O}_{2}$. There were also fuel-specific chromophores such as $\mathrm{C}_{10} \mathrm{H}_{10} \mathrm{O}_{3}$ (distinct isomers for each fuel type), $\mathrm{C}_{8} \mathrm{H}_{10} \mathrm{O}_{3}$ (syringol, brushwood), and $\mathrm{C}_{12} \mathrm{H}_{10} \mathrm{O}_{4}$ (dung).

In this study, we characterized a wide range of particlephase compounds produced by cookstoves, including the lignin-derived $\mathrm{C}_{x} \mathrm{H}_{y} \mathrm{O}_{z}$ compounds that have commonly been identified in wood burning studies, and less common nitrogen-containing compounds. Specifically, from dung cook fires, we detected what we presume to be aromatic nitrogen-containing compounds with few or no oxygen atoms. Our inventory of chemical formulas is just the starting point for comprehensively characterizing particle-phase cookstove emissions. Future efforts should focus on the identification of compounds, precise emission factor quantification for specific compounds, evaluation of toxicity, and modeling the effect of these compounds on secondary air pollution formation in aging smoke plumes.

Data availability. All relevant data have been included in this manuscript in the form of tables. The raw data are available from the corresponding author upon request.

\section{The Supplement related to this article is available online at https://doi.org/10.5194/acp-18-2461-2018-supplement.}

Competing interests. The authors declare that they have no conflicts of interest.

Acknowledgements. The authors would like to acknowledge Sneha Gautam's support of this project. He made sure the needs of the field technicians were met and acted as a consultant in the field. This research was supported by EPA STAR grant R835425 Impacts of household sources on outdoor pollution at village and regional scales in India. The contents are solely the responsibility of the authors and do not necessarily represent the official views of the US EPA. The US EPA does not endorse the purchase of any commercial products or services mentioned in the publication. The authors acknowledge NOAA grants NA16OAR4310101 (PNNL) and NA16OAR4310102 (UCI) for supporting nano-DESI and
HPLC-PDA-HRMS analysis of samples. The HRMS measurements were performed at the W.R. Wiley Environmental Molecular Sciences Laboratory (EMSL) - a national scientific user facility located at PNNL, and sponsored by the Office of Biological and Environmental Research of the U.S. DOE. PNNL is operated for U.S. DOE by Battelle Memorial Institute under Contract No. DE-AC06-76RL0 1830.

Edited by: Eleanor Browne

Reviewed by: Robert Yokelson and one anonymous referee

\section{References}

Anastasio, C., Faust, B. C., and Rao, C. J.: Aromatic Carbonyl Compounds as Aqueous-Phase Photochemical Sources of Hydrogen Peroxide in Acidic Sulfate Aerosols, Fogs, and Clouds. 1. Non-Phenolic Methoxybenzaldehydes and Methoxyacetophenones with Reductants (Phenols), Environ. Sci. Technol., 31, 218-232, https://doi.org/10.1021/es960359g, 1997.

Araujo, J. A., Barajas, B., Kleinman, M., Wang, X., Bennett, B. J., Gong, K. W., Navab, M., Harkema, J., Sioutas, C., Lusis, A. J., and Nel, A. E.: Ambient Particulate Pollutants in the Ultrafine Range Promote Early Atherosclerosis and Systemic Oxidative Stress, Circ. Res., 102, 589-596, https://doi.org/10.1161/CIRCRESAHA.107.164970, 2008.

Balakrishnan, K., Sambandam, S., Ghosh, S., Mukhopadhyay, K., Vaswani, M., Arora, N. K., Jack, D., Pillariseti, A., Bates, M. N., and Smith, K. R.: Household Air Pollution Exposures of Pregnant Women Receiving Advanced Combustion Cookstoves in India: Implications for Intervention, Ann. Glob. Heal., 81, 375385, https://doi.org/10.1016/j.aogh.2015.08.009, 2015.

Bluvshtein, N., Lin, P., Flores, J. M., Segev, L., Mazar, Y., Tas, E., Snider, G., Weagle, C., Brown, S. S., Laskin, A., and Rudich, Y.: Broadband optical properties of biomassburning aerosol and identification of brown carbon chromophores, J. Geophys. Res.-Atmos., 122, 5441-5456, https://doi.org/10.1002/2016JD026230, 2017.

Budisulistiorini, S. H., Riva, M., Williams, M., Chen, J., Itoh, M., Surratt, J. D., and Kuwata, M.: Light-Absorbing Brown Carbon Aerosol Constituents from Combustion of Indonesian Peat and Biomass, Environ. Sci. Technol., 51, 4415-4423, https://doi.org/10.1021/acs.est.7b00397, 2017.

Census of India: Households by Availability of Separate Kitchen and Type of Fuel Used for Cooking, available at: available at: http://www.censusindia.gov.in/2011census/Hlo-series/HH10. html (last access: 8 August 2017), 2011.

Chafe, Z. A., Brauer, M., Klimont, Z., Van Dingenen, R., Mehta, S., Rao, S., Riahi, K., Dentener, F., and Smith, K. R.: Household Cooking with Solid Fuels Contributes to Ambient $\mathrm{PM}_{2.5}$ Air Pollution and the Burden of Disease, Environ. Health Perspect., 122, 1314-1320, https://doi.org/10.1289/ehp.1206340, 2014.

Chen, Y. and Bond, T. C.: Light absorption by organic carbon from wood combustion, Atmos. Chem. Phys., 10, 1773-1787, https://doi.org/10.5194/acp-10-1773-2010, 2010.

Chen, Y., Roden, C. A., and Bond, T. C.: Characterizing Biofuel Combustion with Patterns of Real-Time Emission Data (PaRTED), Environ. Sci. Technol., 46, 6110-6117, https://doi.org/10.1021/es3003348, 2012. 
Coggon, M. M., Veres, P. R., Yuan, B., Koss, A., Warneke, C., Gilman, J. B., Lerner, B. M., Peischl, J., Aikin, K. C., Stockwell, C. E., Hatch, L. E., Ryerson, T. B., Roberts, J. M., Yokelson, R. J., and de Gouw, J. A.: Emissions of nitrogen-containing organic compounds from the burning of herbaceous and arboraceous biomass: Fuel composition dependence and the variability of commonly used nitrile tracers, Geophys. Res. Lett., 43, 99039912, https://doi.org/10.1002/2016GL070562, 2016.

Collard, F.-X. and Blin, J.: A review on pyrolysis of biomass constituents: Mechanisms and composition of the products obtained from the conversion of cellulose, hemicelluloses and lignin, Renew. Sust. Energ. Rev., 38, 594-608, https://doi.org/10.1016/j.rser.2014.06.013, 2014.

Crutzen, P. J. and Andreae, M. O.: Biomass Burning in the Tropics - Impact on Atmospheric Chemistry and Biogeochemical Cycles, Science, 250, 1669-1678, https://doi.org/10.1126/science.250.4988.1669, 1990.

Feng, Y., Ramanathan, V., and Kotamarthi, V. R.: Brown carbon: a significant atmospheric absorber of solar radiation?, Atmos. Chem. Phys., 13, 8607-8621, https://doi.org/10.5194/acp13-8607-2013, 2013.

Finlayson-Pitts, B. J. and Pitts, J. N.: Chemistry of the Upper and Lower Atmosphere: Theory, Experiments, and Applications, Academic Press, San Diego, CA, 2000.

Gautam, S., Edwards, R., Yadav, A., Weltman, R., Pillarsetti, A., Arora, N. K., and Smith, K. R.: Probe-based measurements of moisture in dung fuel for emissions measurements, Energy Sustain. Dev., 35, 1-6, https://doi.org/10.1016/j.esd.2016.09.003, 2016.

Global Alliance for Clean Cookstoves: Protocols: Water Boiling Test, available at: http://cleancookstoves.org/ technology-and-fuels/testing/protocols.html (last access: 6 June 2017), 2014.

Guttikunda, S., Jawahar, P., Gota, S., and KA, N.: UrbanEmissions.info, available at: http://www.urbanemissions.info (last access: 10 August 2017), 2016.

Hatch, L. E., Luo, W., Pankow, J. F., Yokelson, R. J., Stockwell, C. E., and Barsanti, K. C.: Identification and quantification of gaseous organic compounds emitted from biomass burning using two-dimensional gas chromatography-time-offlight mass spectrometry, Atmos. Chem. Phys., 15, 1865-1899, https://doi.org/10.5194/acp-15-1865-2015, 2015.

Hosseini, S., Urbanski, S. P., Dixit, P., Qi, L., Burling, I. R., Yokelson, R. J., Johnson, T. J., Shrivastava, M., Jung, H. S., Weise, D. R., Miller, J. W., and Cocker, D. R.: Laboratory characterization of PM emissions from combustion of wildland biomass fuels, J. Geophys. Res., 118, 9914-9929, https://doi.org/10.1002/jgrd.50481, 2013.

Hughey, C. A., Hendrickson, C. L., Rodgers, R. P., Marshall, A. G., and Qian, K.: Kendrick Mass Defect Spectrum: A Compact Visual Analysis for Ultrahigh-Resolution Broadband Mass Spectra, Anal. Chem., 73, 4676-4681, https://doi.org/10.1021/AC010560W, 2001.

Jayarathne, T., Stockwell, C. E., Bhave, P. V., Praveen, P. S., Rathnayake, C. M., Islam, Md. R., Panday, A. K., Adhikari, S., Maharjan, R., Goetz, J. D., DeCarlo, P. F., Saikawa, E., Yokelson, R. J., and Stone, E. A.: Nepal Ambient Monitoring and Source Testing Experiment (NAMaSTE): Emissions of particulate matter from wood and dung cooking fires, garbage and crop residue burning, brick kilns, and other sources, Atmos. Chem. Phys. Discuss., https://doi.org/10.5194/acp-2017-510, in review, 2017.

Johnson, M., Edwards, R., Alatorre Frenk, C., and Masera, O.: In-field greenhouse gas emissions from cookstoves in rural Mexican households, Atmos. Environ., 42, 1206-1222, https://doi.org/10.1016/j.atmosenv.2007.10.034, 2008.

Johnson, M., Edwards, R., Ghilardi, A., Berrueta, V., Gillen, D., Frenk, C. A., and Masera, O.: Quantification of Carbon Savings from Improved Biomass Cookstove Projects, Environ. Sci. Technol., 43, 2456-2462, https://doi.org/10.1021/es801564u, 2009.

Kirchstetter, T. W., Novakov, T., and Hobbs, P. V.: Evidence that the spectral dependence of light absorption by aerosols is affected by organic carbon, J. Geophys. Res.-Atmos., 109, D21208, https://doi.org/10.1029/2004JD004999, 2004.

Kituyi, E., Marufu, L., Wandiga, S. O., Jumba, I. O., Andreae, M. O., and Helas, G.: Carbon monoxide and nitric oxide from biofuel fires in Kenya, Energy Convers. Manag., 42, 1517-1542, https://doi.org/10.1016/S0196-8904(00)00158-8, 2001.

Lack, D. A. and Langridge, J. M.: On the attribution of black and brown carbon light absorption using the Ångström exponent, Atmos. Chem. Phys., 13, 10535-10543, https://doi.org/10.5194/acp-13-10535-2013, 2013.

Laskin, A., Smith, J. S., and Laskin, J.: Molecular Characterization of Nitrogen-Containing Organic Compounds in Biomass Burning Aerosols Using High-Resolution Mass Spectrometry, Environ. Sci. Technol., 43, 3764-3771, https://doi.org/10.1021/es803456n, 2009.

Laskin, A., Laskin, J., and Nizkorodov, S. A.: Chemistry of Atmospheric Brown Carbon, Chem. Rev., 115, 4335-4382, https://doi.org/10.1021/cr5006167, 2015.

Laskin, J., Laskin, A., Roach, P. J., Slysz, G. W., Anderson, G. A., Nizkorodov, S. A., Bones, D. L., and Nguyen, L. Q. High-Resolution Desorption Electrospray Ionization Mass Spectrometry for Chemical Characterization of Organic Aerosols, Anal. Chem., 82, 2048-2058, https://doi.org/10.1021/ac902801f, 2010.

Lee, S., Baumann, K., Schauer, J. J., Sheesley, R. J., Naeher, L. P., Meinardi, S., Blake, D. R., Edgerton, E. S., Russell, A. G., and Clements, M.: Gaseous and particulate emissions from prescribed burning in Georgia, Environ. Sci. Technol., 39, 90499056, https://doi.org/10.1021/es0515831, 2005.

Lelieveld, J., Evans, J. S., Fnais, M., Giannadaki, D., and Pozzer, A.: The contribution of outdoor air pollution sources to premature mortality on a global scale, Nature, 525, 367-371, https://doi.org/10.1038/nature15371, 2015.

Lin, P., Rincon, A. G., Kalberer, M., and Yu, J. Z.: Elemental Composition of HULIS in the Pearl River Delta Region, China: Results Inferred from Positive and Negative Electrospray High Resolution Mass Spectrometric Data, Environ. Sci. Technol., 46, 7454-7462, https://doi.org/10.1021/es300285d, 2012.

Lin, P., Laskin, J., Nizkorodov, S. A., and Laskin, A.: Revealing Brown Carbon Chromophores Produced in Reactions of Methylglyoxal with Ammonium Sulfate, Environ. Sci. Technol., 49, 14257-14266, https://doi.org/10.1021/acs.est.5b03608, 2015.

Lin, P., Aiona, P. K., Li, Y., Shiraiwa, M., Laskin, J., Nizkorodov, S. A., and Laskin, A.: Molecular Characterization of Brown Carbon in Biomass Burning Aerosol Particles, Environ. Sci. Technol., 50, 11815-11824, https://doi.org/10.1021/acs.est.6b03024, 2016. 
Lin, P., Bluvshtein, N., Rudich, Y., Nizkorodov, S., Laskin, J., and Laskin, A.: Molecular Chemistry of Atmospheric Brown Carbon Inferred from a Nationwide BiomassBurning Event, Environ. Sci. Technol., 51, 11561-11570, https://doi.org/10.1021/acs.est.7b02276, 2017.

Lobert, J. M., Keene, W. C., Logan, J. A., and Yevich, R.: Global chlorine emissions from biomass burning: Reactive Chlorine Emissions Inventory, J. Geophys. Res.-Atmos., 104, 8373-8389, https://doi.org/10.1029/1998JD100077, 1999.

Ludwig, J., Marufu, L. T., Huber, B., Andreae, M. O., and Helas, G.: Domestic Combustion of Biomass Fuels in Developing Countries: A Major Source of Atmospheric Pollutants, J. Atmos. Chem., 44, 23-37, https://doi.org/10.1023/A:1022159910667, 2003.

Mukhopadhyay, R., Sambandam, S., Pillarisetti, A., Jack, D., Mukhopadhyay, K., Balakrishnan, K., Vaswani, M., Bates, M. N., Kinney, P. L., Arora, N., and Smith, K. R.: Cooking practices, air quality, and the acceptability of advanced cookstoves in Haryana, India: an exploratory study to inform large-scale interventions, Glob. Health Action, 5, 1-13, https://doi.org/10.3402/gha.v5i0.19016, 2012.

Pandey, A., Pervez, S., and Chakrabarty, R. K.: Filter-based measurements of UV-vis mass absorption cross sections of organic carbon aerosol from residential biomass combustion: Preliminary findings and sources of uncertainty, J. Quant. Spectrosc. Ra., 182, 296-304, https://doi.org/10.1016/j.jqsrt.2016.06.023, 2016.

Pillarisetti, A., Vaswani, M., Jack, D., Balakrishnan, K., Bates, M. N., Arora, N. K., and Smith, K. R.: Patterns of Stove Usage after Introduction of an Advanced Cookstove: The Long-Term Application of Household Sensors, Environ. Sci. Technol., 48, 1452514533, https://doi.org/10.1021/es504624c, 2014.

Pluskal, T., Castillo, S., Villar-Briones, A., and Orešič, M.: MZmine 2: Modular framework for processing, visualizing, and analyzing mass spectrometry-based molecular profile data, BMC Bioinformatics, 11, 395, https://doi.org/10.1186/1471-2105-11-395, 2010.

Purcell, J. M., Rodgers, R. P., Hendrickson, C. L., and Marshall, A. G.: Speciation of nitrogen containing aromatics by atmospheric pressure photoionization or electrospray ionization fourier transform ion cyclotron resonance mass spectrometry, J. Am. Soc. Mass Spectr., 18, 1265-1273, https://doi.org/10.1016/j.jasms.2007.03.030, 2007.

Roach, P. J., Laskin, J., and Laskin, A.: Molecular Characterization of Organic Aerosols Using Nanospray-Desorption/Electrospray Ionization-Mass Spectrometry, Anal. Chem., 82, 7979-7986, https://doi.org/10.1021/ac101449p, 2010a.

Roach, P. J., Laskin, J., and Laskin, A.: Nanospray desorption electrospray ionization: an ambient method for liquid-extraction surface sampling in mass spectrometry, Analyst, 135, 2233-2236, https://doi.org/10.1039/c0an00312c, 2010b.

Roach, P. J., Laskin, J., and Laskin, A.: Higher-Order Mass Defect Analysis for Mass Spectra of Complex Organic Mixtures, Anal. Chem., 83, 4924-4929, https://doi.org/10.1021/ac200654j, 2011.

Roden, C. A., Bond, T. C., Conway, S., Osorto Pinel, A. B., MacCarty, N., and Still, D.: Laboratory and field investigations of particulate and carbon monoxide emissions from traditional and improved cookstoves, Atmos. Environ., 43, 11701181, https://doi.org/10.1016/j.atmosenv.2008.05.041, 2009.
Saleh, R., Robinson, E. S., Tkacik, D. S., Ahern, A. T., Liu, S., Aiken, A. C., Sullivan, R. C., Presto, A. A., Dubey, M. K., Yokelson, R. J., Donahue, N. M., and Robinson, A. L.: Brownness of organics in aerosols from biomass burning linked to their black carbon content, Nat. Geosci., 7, 647-650, 2014.

Simoneit, B. R. T.: Biomass burning - a review of organic tracers for smoke from incomplete combustion, Appl. Geochemistry, 17, 129-162, https://doi.org/10.1016/S0883-2927(01)00061-0, 2002.

Simoneit, B. R. T., Rogge, W. F., Mazurek, M. A., Standley, L. J., Hildemann, L. M., and Cass, G. R.: Lignin pyrolysis products, lignans, and resin acids as specific tracers of plant classes in emissions from biomass combustion, Environ. Sci. Technol., 27, 2533-2541, https://doi.org/10.1021/es00048a034, 1993.

Simoneit, B. R. T., Schauer, J. J., Nolte, C. G., Oros, D. R., Elias, V. O., Fraser, M. P., Rogge, W. F., and Cass, G. R.: Levoglucosan, a tracer for cellulose in biomass burning and atmospheric particles, Atmos. Environ., 33, 173-182, https://doi.org/10.1016/S13522310(98)00145-9, 1999.

Smith, J. S., Laskin, A., and Laskin, J.: Molecular Characterization of Biomass Burning Aerosols Using HighResolution Mass Spectrometry, Anal. Chem., 81, 1512-1521, https://doi.org/10.1021/ac8020664, 2009.

Smith, K. R., Bruce, N., Balakrishnan, K., Adair-Rohani, H., Balmes, J., Chafe, Z., Dherani, M., Hosgood, H. D., Mehta, S., Pope, D., Rehfuess, E., and HAP CRA Risk Expert Group: Millions dead: how do we know and what does it mean? Methods used in the comparative risk assessment of household air pollution., Annu. Rev. Public Health, 35, 185-206, https://doi.org/10.1146/annurevpublhealth-032013-182356, 2014.

Stockwell, C. E., Christian, T. J., Goetz, J. D., Jayarathne, T., Bhave, P. V., Praveen, P. S., Adhikari, S., Maharjan, R., DeCarlo, P. F., Stone, E. A., Saikawa, E., Blake, D. R., Simpson, I. J., Yokelson, R. J., and Panday, A. K.: Nepal Ambient Monitoring and Source Testing Experiment (NAMaSTE): emissions of trace gases and light-absorbing carbon from wood and dung cooking fires, garbage and crop residue burning, brick kilns, and other sources, Atmos. Chem. Phys., 16, 11043-11081, https://doi.org/10.5194/acp-16-11043-2016, 2016.

Sullivan, A. P., May, A. A., Lee, T., McMeeking, G. R., Kreidenweis, S. M., Akagi, S. K., Yokelson, R. J., Urbanski, S. P., and Collett Jr., J. L.: Airborne characterization of smoke marker ratios from prescribed burning, Atmos. Chem. Phys., 14, 1053510545, https://doi.org/10.5194/acp-14-10535-2014, 2014.

Talrose, V., Yermakov, A. N., Usov, A. A., Goncharova, A. A., Leskin, A. N., Messineva, N. A., Trusova, N. V., and Efimkina, M. V.: UV/Visible Spectra, in NIST Chemistry WebBook, NIST Standard Reference Database Number 69, edited by: Linstrom, P. J. and Mallard, W. G., National Institute of Standards and Technology, Gaithersburg MD, 20899., 2017.

Wan, E. C. H. and Yu, J. Z.: Determination of sugar compounds in atmospheric aerosols by liquid chromatography combined with positive electrospray ionization mass spectrometry, J. Chromatogr. A, 1107, 175-181, https://doi.org/10.1016/j.chroma.2005.12.062, 2006. 
Wang, Y., Hu, M., Lin, P., Guo, Q., Wu, Z., Li, M., Zeng, L., Song, Y., Zeng, L., Wu, Y., Guo, S., Huang, X., and He, L.: Molecular Characterization of Nitrogen-Containing Organic Compounds in Humic-like Substances Emitted from Straw Residue Burning, Environ. Sci. Technol., 51, 5951-5961, https://doi.org/10.1021/acs.est.7b00248, 2017.

Willoughby, A., Wozniak, A., and Hatcher, P.: Detailed Source-Specific Molecular Composition of Ambient Aerosol Organic Matter Using Ultrahigh Resolution Mass Spectrometry and ${ }^{1} \mathrm{H}$ NMR, Atmosphere, 7, 79, https://doi.org/10.3390/atmos7060079, 2016.
Xiao, Q. Y., Saikawa, E., Yokelson, R. J., Chen, P. F., Li, C. L., and Kang, S. C.: Indoor air pollution from burning yak dung as a household fuel in Tibet, Atmos. Environ., 102, 406-412, https://doi.org/10.1016/j.atmosenv.2014.11.060, 2015. 